de Ronde, C.E.J., Humphris, S.E., Höfig, T.W., and the Expedition 376 Scientists

Proceedings of the International Ocean Discovery Program Volume 376

publications.iodp.org

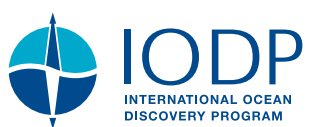

https://doi.org/10.14379/iodp.proc.376.107.2019

Check for updates

Site U1531 ${ }^{1}$

C.E.J. de Ronde, S.E. Humphris, T.W. Höfig, P.A. Brandl, L. Cai, Y. Cai,

F. Caratori Tontini, J.R. Deans, A. Farough, J.W. Jamieson, K.P. Kolandaivelu,

A. Kutovaya, J.M. Labonté, A.J. Martin, C. Massiot, J.M. McDermott, I.M. McIntosh, T. Nozaki, V.H. Pellizari, A.G. Reyes, S. Roberts, O. Rouxel, L.E.M. Schlicht, J.H. Seo, S.M. Straub, K. Strehlow, K. Takai, D. Tanner, F.J. Tepley III, and C. Zhang ${ }^{2}$

Keywords: International Ocean Discovery Program, IODP, JOIDES Resolution, Expedition 376, Brothers Arc Flux, Brothers volcano, Site U1531, Kermadec arc, submarine arc volcano, hydrothermal systems, volcaniclastics, dacite lava, hydrothermal alteration, borehole fluids, hypersaline brine, fluid inclusions, acidic fluids, alteration mineral assemblages, Upper Cone, Lower Cone, NW Caldera

Contents
1 Summary
2 Background and objectives
3 Operations
6 Igneous petrology and volcanology
9 Alteration
10 Structural geology
10 Geochemistry
11 Paleomagnetism
$\mathbf{1 3}$ Physical properties
$\mathbf{1 5}$ Downhole measurements
$\mathbf{1 5}$ Microbiology
$\mathbf{1 6}$ References

\section{Summary Background and objectives}

Site U1531 (proposed alternate Site LC-1A) is located on the saddle between the Lower and Upper Cones of Brothers volcano at $34^{\circ} 52.7767^{\prime} \mathrm{S}, 179^{\circ} 04.2241 \mathrm{E}$ about $380 \mathrm{~m}$ northeast of Seismic Line Bro-3 at a water depth of $1355 \mathrm{~m}$. This site likely sits between the margins of the upflow zones of both the Upper and Lower Cones because no detectable magnetic low was measured in this area. The Lower Cone hydrothermal vent field includes vents that discharge the most $\mathrm{Fe}$ - and $\mathrm{Mg}$-rich fluids sampled at Brothers volcano to date, although venting at the saddle was not found. The main objective at Site U1531 was to drill and core to $\sim 300$ meters below seafloor (mbsf) to sample the various volcanic cycles that constructed the Lower Cone and to intersect the marginal upflow zone of hydrothermal fluids.

\section{Operations}

We implemented operations in five holes at Site U1531. Holes U1531A, U1531B, and U1531E were drilled on the saddle between the Lower and Upper Cones of Brothers volcano. Holes U1531C and U1531D were sited on the summit of the Lower Cone. Hole U1531A is located at $34^{\circ} 52.7767^{\prime} \mathrm{S}, 179^{\circ} 4.2241 \mathrm{E}$ at a water depth of $1354.9 \mathrm{~m}$. In this hole, we conducted rotary core barrel (RCB) coring from the seafloor to $15 \mathrm{mbsf}$ with poor recovery $(1.0 \mathrm{~m}$, or $7 \%)$. Any further advancement was impossible because of very poor hole conditions that led to a stuck drill string several times. We then cored with the RCB system in Hole U1531B, which is located at $34^{\circ} 52.7721^{\prime} \mathrm{S}$, $179^{\circ} 4.2111^{\prime} \mathrm{E}$ at a water depth of $1351.9 \mathrm{~m}$. Coring in Hole U1531B penetrated from the seafloor to $26 \mathrm{mbsf}$ and recovered $4.0 \mathrm{~m}$ (15\%).
However, poor hole conditions in blocky/fragmented lava deposits prevented us from further deepening this hole.

We offset the vessel $\sim 110 \mathrm{~m}$ northeastward to the summit of the Lower Cone where Hole U1531C is located at $34^{\circ} 52.7239^{\prime} \mathrm{S}$, $179^{\circ} 4.2586 \mathrm{E}$ at a water depth of $1306.9 \mathrm{~m}$. In this hole, we cored with the RCB system from the seafloor to $28.4 \mathrm{mbsf}$ and recovered $2.3 \mathrm{~m}(8 \%)$; there were tight hole conditions throughout coring; thus, we abandoned Hole U1531C at $28.4 \mathrm{mbsf}$. We then decided to deploy a reentry system with a short $16 \mathrm{~m}$ casing string to establish a stable hole for reaching deeper coring and logging objectives. We drilled-in casing in Hole U1531D, located at $34^{\circ} 52.7228^{\prime} \mathrm{S}$, $179^{\circ} 4.2606$ ' $\mathrm{E}$ at a water depth of $1306.9 \mathrm{~m}$ at the summit of the Lower Cone. After the pilot bit drilled to the target depth of 19 mbsf, we released the reentry system from the drilling assembly (mud motor, underreamer, and drill bit), but we were unable to pull the drilling assembly clear of the casing string because the underreamer arms did not completely retract. After several hours of attempting to free the reentry system, we started pulling the drill string and attached reentry system out of the hole and back to the vessel. While we were retrieving the casing-reentry system assembly, it unfortunately dropped off in sight of the moonpool. The ship's position at the time was above the lower slope of the Lower Cone in its transition to the nearby southeastern caldera floor.

Finally, we moved back to the saddle between the Lower and Upper Cones and made up another drilling assembly to drill-in 16 $\mathrm{m}$ of casing in Hole U1531E, located at $34^{\circ} 52.7591^{\prime} \mathrm{S}, 179^{\circ} 4.2344^{\prime} \mathrm{E}$ at a water depth of $1355.0 \mathrm{~m}$. We drilled-in the casing to $17.9 \mathrm{mbsf}$. We then conducted another test of the Center for Deep Earth Exploration (CDEX) turbine-driven coring system (TDCS), which washed down (drilled without coring) to 17.9 mbsf to start coring in

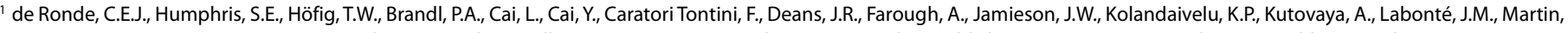
A.J., Massiot, C., McDermott, J.M., McIntosh, I.M., Nozaki, T., Pellizari, V.H., Reyes, A.G., Roberts, S., Rouxel, O., Schlicht, L.E.M., Seo, J.H., Straub, S.M., Strehlow, K., Takai, K., Tanner, D., Tepley, F.J., III, and Zhang, C., 2019. Site U1531. In de Ronde, C.E.J., Humphris, S.E., Höfig, T.W., and the Expedition 376 Scientists, Brothers Arc Flux. Proceedings of the International Ocean Discovery Program, 376: College Station, TX (International Ocean Discovery Program). https://doi.org/10.14379/iodp.proc.376.107.2019

2 Expedition 376 Scientists' affiliations.

MS 376-107: Published 5 July 2019

This work is distributed under the Creative Commons Attribution 4.0 International (CC BY 4.0) license. (c))BY
} 
Hole U1531E. We could not advance any deeper because the TDCS core barrel got stuck in the bottom-hole assembly (BHA) and could not be retrieved. After the TDCS test, we cored with the RCB system from 17.9 to $39.6 \mathrm{mbsf}$ and recovered only $0.8 \mathrm{~m} \mathrm{(4 \% ).} \mathrm{At} \mathrm{this}$ point, the blower motor in the top drive failed. We decided not to repair it at this time because of our remaining scientific priorities and the impending end of the expedition. Our final operation at Site U1531 consisted of a downhole temperature measurement with the Elevated Borehole Temperature Sensor (ETBS) memory tool. The tool recorded a maximum temperature of $\sim 5^{\circ} \mathrm{C}$ at $20 \mathrm{mbsf}$. In total, 264.25 h, or 11.01 days, were spent at Site U1531.

\section{Principal results \\ Igneous petrology and volcanology}

At Site U1531, one igneous unit was observed in Holes U1531A (0-1.14 mbsf), U1531B (0-21.97 mbsf), U1531C (0-23.75 mbsf), and U1531E (17.90-34.95 mbsf) as well as in several "ghost cores" from Hole U1531E. Igneous Unit 1 consists of unaltered to slightly altered plagioclase-pyroxene-phyric dacite lava intercalated with unconsolidated ash, ash with lapilli, and lapilli tephra with ash. The moderately to highly vesicular dacite lava contains glomerocrysts and phenocrysts of plagioclase, orthopyroxene, and clinopyroxene and Fe-Ti oxides in a cryptocrystalline and hypocrystalline groundmass. Volcaniclastic material is mainly composed of unaltered dacite clasts, crystals, and subordinate lithic components. The composition of the dacite lava and pyroclastic rocks from Site U1531 is similar to that of dacite cored in the upper sections at Sites U1527 and U1529.

\section{Alteration}

One alteration type was identified at Site U1531 based on an alteration assemblage identified using a combination of macroscopic and microscopic descriptions and X-ray diffraction (XRD) analyses. Alteration Type I is classified as slightly altered and has an alteration mineral assemblage of smectite, Fe oxyhydroxide, zeolite, pyrite, and rare native sulfur. Alteration occurs as infilling and lining of vesicles and smectite replacing the glassy matrix.

\section{Structural geology}

The main structures at Site U1531 include volcanic fabrics and fractures. Volcanic fabrics ranging from weak to strong were observed in all holes. Only three depth intervals across Site U1531 are structurally isotropic. Fabrics are defined by elongated vesicles, plagioclase microlites, and subordinate plagioclase phenocrysts and glomerocrysts. Vesicles have aspect ratios between 5 and 15 . Hole $\mathrm{U} 1531 \mathrm{C}$ is the only hole where fabric orientation was measured. Fabric dips range from moderate to steep. A few pieces in Hole U1531C have lineations defined by vesicles; all plunges are subparallel to the dip. Several core pieces from all holes have microfractures delineated by the growth of halite and gypsum after pieces were cut and dried. Discrete fractures are best preserved in Hole U1531C. Fractures range from shallow to steep and are typically marked by secondary minerals such as native sulfur or Fe oxyhydroxide.

\section{Geochemistry}

Unaltered to slightly altered lava and tephra from Igneous Unit 1 represent typical dacites and have 62.3 to $65.0 \mathrm{wt} \% \mathrm{SiO}_{2}$ and 6.5 to $6.9 \mathrm{wt} \% \mathrm{Na}_{2} \mathrm{O}+\mathrm{K}_{2} \mathrm{O}$. They are essentially similar in major and trace element composition to fresh dacites from Site U1529 and Hole U1527A (Unit 1) and confirm the low compositional range previously reported for dacite at Brothers volcano. Total carbon (TC) and total sulfur concentrations are generally low $(<250$ and $<300 \mu \mathrm{g} / \mathrm{g}$, respectively), except for one sample with a TC value of $\sim 1900 \mu \mathrm{g} / \mathrm{g}$. Low total sulfur is consistent with previously reported data for dacitic glass at Brothers volcano and suggests minimal influence of magmatic volatile input in selected samples. Nevertheless, relatively high concentrations of pore space $\mathrm{H}_{2}$ and acid volatile sulfide were detected in some intervals and may be indicative of discharging magmatic gases through the volcanic pile.

\section{Paleomagnetism}

Only three core sections recovered from Site U1531 (i.e., Hole U1531C) had oriented pieces that could be measured in the cryogenic superconducting rock magnetometer (SRM). In addition, we selected five discrete samples from the working halves for detailed measurements of anisotropy magnetic susceptibility (AMS), alternating field (AF), thermal demagnetization (TD), and isothermal remanent magnetization (IRM) experiments. As expected from fresh dacites, the natural remanent magnetization (NRM) intensity values are large. Magnetic directions from these samples have inclinations of approximately $-60^{\circ}$, suggesting a very young age for the primary magnetization component. The shape of the TD curve indicates that these samples contain pure magnetite and titanomagnetite with variable Ti contents.

\section{Physical properties}

Physical property measurements made on limited fragmented core recovered from Holes U1531A-U1531C and U1531E are consistent with the range of expected values for fresh dacite lava and tephra and are similar to those for fresh volcaniclastic material from Igneous Unit 1 at Sites U1527-U1529. No clear difference in physical properties between material recovered from the summit of the Lower Cone and material recovered from the saddle was found, although interpretation is significantly limited by the low recovery, fragmented nature of the core, and limited number of oriented pieces.

\section{Downhole measurements}

The ETBS memory tool was deployed in Hole U1531E after $\sim 24$ $\mathrm{h}$ without circulation. The tool recorded a maximum temperature of $5.2^{\circ} \mathrm{C}$ at $20 \mathrm{mbsf}$, which is similar to the bottom seawater temperature.

\section{Microbiology}

One whole-round sample of moderately vesicular dacite lava was collected from Hole U1531C for microbiological analysis. Sample aliquots were taken and preserved for shore-based DNA and RNA analyses and prokaryotic and viral counting and activity measurements.

\section{Background and objectives}

Site U1531 is located at $34^{\circ} 52.7758^{\prime} \mathrm{S}, 179^{\circ} 04.2186^{\prime} \mathrm{E}$, on the saddle between the Lower and Upper Cones of Brothers volcano 380 $\mathrm{m}$ northeast of Seismic Line Bro-3 at a water depth of $1359 \mathrm{~m}$ (Figure F1). The site likely sits between the margins of the upflow zones of both the Upper and Lower Cones, considering that no measurable magnetic low is found in this area. The Lower Cone hydrothermal vent field includes vents that discharge the most Fe- and Mgrich fluids sampled at Brothers volcano to date. However, no evidence for venting at the saddle has been found, although venting was observed $\sim 120 \mathrm{~m}$ northeast of the saddle on the flanks of the Lower Cone. A marker was placed at the proposed site in early 2017 with the remotely operated vehicle Quest 4000. 
Figure F1. Detailed bathymetry of Brothers volcano and surrounding area showing the location of sites drilled during Expedition 376. Contour interval $=200 \mathrm{~m}$. Modified from Embley et al. (2012).

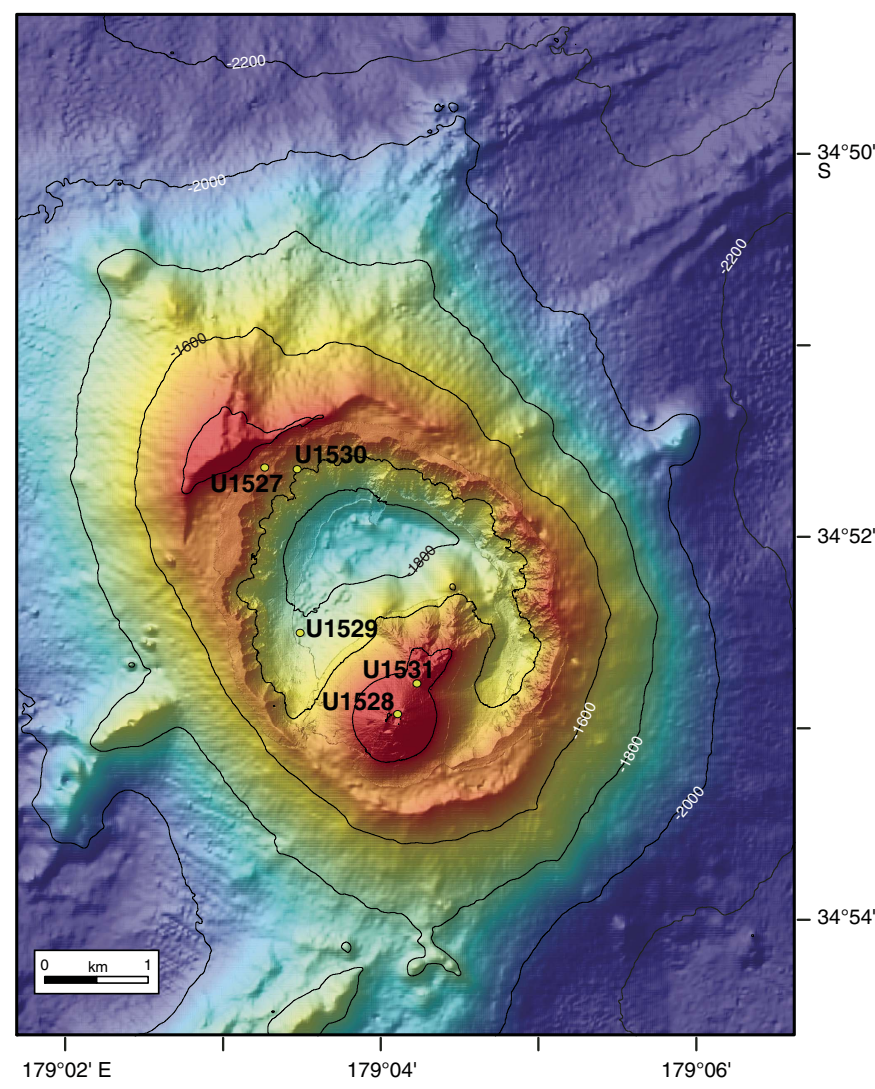

The plan for Site U1531 was to drill and core to $\sim 300 \mathrm{mbsf}$ to transect the various volcanic cycles that constructed the Lower Cone and to intersect the marginal upflow zone of hydrothermal fluids (de Ronde et al., 2017). Lithologies similar to those encountered at Site U1528 (i.e., dacite lava and volcaniclastic material, both affected by varying degrees of advanced argillic alteration) were expected.

\section{Operations}

Site U1531 consists of five holes. The original plan for this site was to drill two holes: a pilot hole to core to $\sim 50 \mathrm{mbsf}$ with the RCB system (see Figure F3 in the Site U1527 chapter [de Ronde et al., 2019b]) and a second hole to drill-in a reentry system to a depth based on conditions encountered in the pilot hole followed by coring to $300 \mathrm{mbsf}$. Actual operations proved much different. Hole U1531A was cored with the RCB system to $15.0 \mathrm{mbsf}$ in the saddle between the Upper and Lower Cones of Brothers volcano. Coring was terminated when we could not retrieve the first core barrel and had to pull clear of the seafloor because of high torque and high overpull.

Hole U1531B reached 24.0 mbsf with Core 376-U1531B-3R, but hole conditions were again very poor and there was high torque and overpull during the entire interval of blocky, fragmented volcanic and volcaniclastic deposits. We then moved northeast, up the slope of the Lower Cone $\sim 110 \mathrm{~m}$ to its summit area, and attempted another pilot hole (U1531C). Coring here also had very limited success, with only three cores retrieved before terminating at $28.4 \mathrm{mbsf}$. Again, high torque and high overpull prevented further coring.
We attempted to drill-in a reentry system through the upper section of the formation. A reentry system and 13\%3 inch $(\sim 34.0 \mathrm{~cm})$ casing for Hole U1531D was drilled-in, but after releasing the system from the hanger, we were unable to release it from the casing, most probably because the underreamer arms failed to close completely. Forced to pull out of the seafloor with the reentry system still attached, we offset the ship $400 \mathrm{~m}$ east in case the system fell while we were retrieving it. Indeed, the system did fall to the seafloor just before it could be recovered and was later located during a seafloor camera survey to record its position at $34^{\circ} 52.7254^{\prime} \mathrm{S}$, $179^{\circ} 04.5434 \mathrm{E}$ at an approximate water depth of $1490 \mathrm{~m}$. It was seen to be standing perfectly upright, having penetrated $\sim 10 \mathrm{~m}$ into the sediments covering the southeast part of the caldera floor.

A second, similar reentry system was constructed for Hole U1531E with $\sim 15 \mathrm{~m}$ of $13 \% 3$ inch casing. We experienced similar problems when releasing it from the casing, although we were finally able to do so. We attempted to test the TDCS, but a stuck core barrel at the beginning of the test forced us to abandon coring with the TDCS. The RCB coring system was able to core to $39.6 \mathrm{mbsf}$, but again there was high torque on the drill string throughout. Before we could abandon coring, an equipment failure on the top drive drilling system caused us to end coring slightly ahead of our planned termination time. After a short interlude to return to Hole U1528D for fluid sampling and temperature measurements, we returned to Site U1531 for downhole temperature measurements with the ETBS memory tool in Hole U1531E. The tool recorded a value similar to that of bottom seawater temperature. In total, $264.25 \mathrm{~h}$, or 11.0 days, were spent at Site U1531.

\section{Hole U1531A}

While we were recovering the drill string from Hole U1530A, we began moving the vessel to the shallower water Site U1531 using the ship's dynamic positioning system. At 1806 h on 20 June 2018, we arrived at Site U1531, located on the saddle between the Upper and Lower Cones. The end of the drill string (the mechanical bit release [MBR]) arrived back on the rig floor at $2005 \mathrm{~h}$ on 20 June, officially ending Hole U1530A. We reassembled the rig floor and conducted a routine cut-and-slip of the drilling line before operations were stopped because of storm-force winds and high seas. The following $35.75 \mathrm{~h}$ was spent waiting for the weather to improve sufficiently so that we could continue operations.

At 1000 h on 22 June, we made up an RCB BHA (see Figure F4 in the Site U1527 chapter [de Ronde et al., 2019b]) and lowered it to the seafloor. At $1430 \mathrm{~h}$, we deployed the subsea camera system to perform a seafloor survey to ensure the absence of vent-related animals and to verify the exact seafloor depth at three potential hole locations. After retrieving the subsea camera system and picking up the top drive, we started RCB coring in Hole U1531A at $2030 \mathrm{~h}$. Core 376-U1531A-1R penetrated from the seafloor to $15 \mathrm{mbsf}$, but we experienced excessive torque and overpull and had to pull the drill string out of the hole. After the bit cleared the seafloor at 2330 $\mathrm{h}$, we lowered the core line to retrieve Core $1 \mathrm{R}$ (1.5 m recovered; $7 \%)$ at $0045 \mathrm{~h}$ on 23 June. All cores, penetration depths, core recovery, and times recovered on deck are displayed in Table T1. The time spent in Hole U1531A was 51.5 h, or 2.1 days, including 35.75 $\mathrm{h}$ of waiting for the weather to improve.

\section{Hole U1531B}

We started RCB coring in Hole U1531B. Cores 376-U1531B-1R through $3 \mathrm{R}$ penetrated from the seafloor to $26 \mathrm{mbsf}$ and recovered 
Table T1. Core summary, Site U1531. * = center bit deployment. DRF = drilling depth below rig floor, DSF = drilling depth below seafloor. Core type: R = rotary core barrel, $\mathrm{G}=$ ghost core, numeric core type $=$ drilled interval. $\mathrm{N}-\mathrm{Mag}=$ nonmagnetic. $\mathrm{SP}=$ shear pin, $\mathrm{WL}=$ wireline, $\mathrm{F}=$ from, TDCS $=$ turbine-driven coring system. Totals from Hole U1531E exclude drilled interval. (Continued on next page.) Download table in CSV format.

\section{Hole U1531A}

Latitude: $34^{\circ} 52.7767^{\prime} \mathrm{S}$

Longitude: $179^{\circ} 4.2241^{\prime} \mathrm{E}$

Seafloor (drill pipe measurement below rig floor, $m$ DRF): 1366.0

Time on hole (days): 2.1

Total depth (drill pipe measurement from rig floor, $\mathrm{m} \mathrm{DRF):} 1381.0$

Distance between rig floor and sea level $(\mathrm{m}): 11.1$

Total penetration (drilling depth below seafloor, $\mathrm{m} \mathrm{DSF}$ ): 15.0

Total length of cored section $(\mathrm{m}): 15.0$

Total core recovered $(\mathrm{m}): 1.0$

Core recovery (\%): 6.7

Drilled interval $(\mathrm{m}): 0$

Total cores (no.): 1

\section{Hole U1531C}

Latitude: $34^{\circ} 52.7239^{\prime} \mathrm{S}$

Longitude: $179^{\circ} 4.2586^{\prime} \mathrm{E}$

Seafloor (drill pipe measurement below rig floor, m DRF): 1318.0

Time on hole (days): 1.0

Total depth (drill pipe measurement from rig floor, m DRF): 1346.4

Distance between rig floor and sea level $(\mathrm{m}): 11.1$

Total penetration (drilling depth below seafloor, $\mathrm{m} \mathrm{DSF):} 28.4$

Total length of cored section $(\mathrm{m}): 28.4$

Total core recovered $(\mathrm{m}): 2.3$

Core recovery (\%): 7.9

Drilled interval $(\mathrm{m}): 0$

Total cores (no.): 3

\section{Hole U1531E}

\section{Latitude: $34^{\circ} 52.7591^{\prime} \mathrm{S}$}

Longitude: $179^{\circ} 4.2344^{\prime} \mathrm{E}$

Seafloor (drill pipe measurement below rig floor, $\mathrm{m}$ DRF): 1361.5

Time on hole (days): 5.6

Total depth (drill pipe measurement from rig floor, m DRF): 1401.1

Distance between rig floor and sea level $(\mathrm{m}): 11.1$

Total penetration (drilling depth below seafloor, $\mathrm{m} \mathrm{DSF):} 39.6$

Total length of cored section $(\mathrm{m}): 21.7$

Total core recovered $(\mathrm{m}): 0.8$

Core recovery (\%): 3.6

Drilled interval $(\mathrm{m}): 17.9$

Total cores (no.): 5

\section{Hole U1531B}

Latitude: $34^{\circ} 52.7721^{\prime} \mathrm{S}$

Longitude: $179^{\circ} 4.2111^{\prime} \mathrm{E}$

Seafloor (drill pipe measurement below rig floor, m DRF): 1363.0

Time on hole (days): 0.6

Total depth (drill pipe measurement from rig floor, m DRF): 1389.0

Distance between rig floor and sea level $(\mathrm{m}): 11.1$

Total penetration (drilling depth below seafloor, $\mathrm{m}$ DSF): 26.0

Total length of cored section $(\mathrm{m}): 26.0$

Total core recovered $(\mathrm{m}): 4.0$

Core recovery (\%): 5.8

Drilled interval $(\mathrm{m}): 0$

Total cores (no.): 3

\section{Hole U1531D}

Latitude: $34^{\circ} 52.7228^{\prime} \mathrm{S}$

Longitude: $179^{\circ} 4.2606^{\prime} \mathrm{E}$

Seafloor (drill pipe measurement below rig floor, $\mathrm{m} \mathrm{DRF):} 1318.0$

Time on hole (days): 1.5

Total depth (drill pipe measurement from rig floor, $\mathrm{m}$ DRF): 1337.0

Distance between rig floor and sea level $(\mathrm{m}): 11.1$

Total penetration (drilling depth below seafloor, $\mathrm{m} \mathrm{DSF}$ ): 19.0

Total length of cored section $(\mathrm{m}): 0$

Total core recovered $(\mathrm{m}): 0$

Core recovery (\%): 0

Drilled interval (m): 19

Total cores (no.): 0

\begin{tabular}{|c|c|c|c|c|c|c|c|c|c|c|c|c|}
\hline Core & $\begin{array}{c}\text { Top of } \\
\text { Interval } \\
\text { DSF (m) }\end{array}$ & $\begin{array}{l}\text { Bottom of } \\
\text { Interval } \\
\text { DSF }(m)\end{array}$ & $\begin{array}{l}\text { Interval } \\
\text { advanced } \\
\text { (m) }\end{array}$ & $\begin{array}{l}\text { Recovered } \\
\text { length } \\
(\mathrm{m})\end{array}$ & $\begin{array}{l}\text { Curated } \\
\text { length } \\
\text { (m) }\end{array}$ & $\begin{array}{l}\text { Recovery } \\
\text { (\%) }\end{array}$ & $\begin{array}{c}\text { Date on } \\
\text { deck } \\
(2018)\end{array}$ & $\begin{array}{c}\text { Time on } \\
\text { deck UTC } \\
\text { (h) }\end{array}$ & $\begin{array}{l}\text { Time to } \\
\text { cut core } \\
\text { (min) }\end{array}$ & $\begin{array}{l}\text { Core } \\
\text { barrel }\end{array}$ & $\begin{array}{l}\text { Mud } \\
\text { pumped } \\
\text { (bbl) }\end{array}$ & Driller's notes \\
\hline \multicolumn{13}{|c|}{ 376-U1531A- } \\
\hline \multirow[t]{2}{*}{$1 \mathrm{R}$} & 0.0 & 15.0 & 15.0 & 1.00 & 1.14 & 7 & 22 Jun & 0025 & 145 & N-Mag & & Excess torque and overpull \\
\hline & Hole & 1531A totals: & 15.0 & 1.00 & 1.14 & 6.67 & & & & & & \\
\hline \multicolumn{13}{|c|}{ 376-U1531B- } \\
\hline $1 \mathrm{R}$ & 0.0 & 8.7 & 8.7 & 0.50 & 0.50 & 6 & 22 Jun & 1535 & 120 & N-Mag & & \\
\hline $2 \mathrm{R}$ & 8.7 & 18.3 & 9.6 & 0.35 & 0.42 & 4 & 22 Jun & 1930 & 130 & N-Mag & 30 & Temperature strip \\
\hline \multirow{2}{*}{$3 R$} & 18.3 & 26.0 & 7.7 & 3.13 & 3.67 & 41 & 23 Jun & 0255 & 90 & N-Mag & 30 & \\
\hline & Hole & 1531B totals: & 8.7 & 0.50 & 0.50 & 5.75 & & & & & & \\
\hline \multicolumn{13}{|c|}{ 376-U1531C- } \\
\hline $1 \mathrm{R}$ & 0.0 & 15.0 & 15.0 & 1.75 & 2.35 & 12 & 23 Jun & 1220 & 220 & N-Mag & 60 & \\
\hline $2 \mathrm{R}$ & 15.0 & 23.6 & 8.6 & 0.40 & 0.53 & 5 & 23 Jun & 1550 & 90 & N-Mag & 30 & $\begin{array}{l}\text { 2-4 temperature strips; sweep } \\
\text { with heavy mud }\end{array}$ \\
\hline \multirow[t]{2}{*}{$3 R$} & 23.6 & 28.4 & 4.8 & 0.10 & 0.15 & 2 & 23 Jun & 1930 & 80 & N-Mag & 60 & $\begin{array}{l}\text { Sweep with heavy mud; retrieved } \\
\text { Core } 4 R \text {, failed SP, } 2 \text { runs }\end{array}$ \\
\hline & Hole & $1531 C$ totals: & 28.4 & 2.25 & 3.03 & 7.92 & & & & & & \\
\hline \multicolumn{13}{|c|}{ 376-U1531D- } \\
\hline 11 & 0.0 & 19.0 & $* * * * * D$ & rilled from $0 . c$ & to $19.0 \mathrm{~m} \mathrm{~L}$ & $\mathrm{~F}^{* * * * *}$ & 25 Jun & 0245 & 245 & C-BIT* & 110 & Drill-in 13-3/8 inch casing \\
\hline \multicolumn{13}{|c|}{ 376-U1531E- } \\
\hline 11 & 0.0 & 17.9 & 17.9 & 0.00 & 0.50 & & 28 Jun & 0430 & 325 & C-BIT* & 240 & Drill-in casing \\
\hline $2 \mathrm{G}$ & 17.9 & 17.9 & 0.0 & 0.50 & 0.38 & & 29 Jun & 0520 & 45 & N-Mag & 70 & $\begin{array}{l}1 \text { WL for dummy run F/turbine } \\
\text { TDCS, } 1 \text { core, } 2 \text { F/stuck barrel }\end{array}$ \\
\hline $3 G$ & 17.9 & 17.9 & 0.0 & 1.75 & 1.76 & & 29 Jun & 1600 & & N-Mag & & \\
\hline $4 G$ & 17.9 & 17.9 & 0.0 & 0.15 & 0.16 & & 30 Jun & 0330 & 35 & N-Mag & 100 & Tagged hard fill at $14 \mathrm{~m}$ \\
\hline
\end{tabular}


Table T1 (continued).

\begin{tabular}{|c|c|c|c|c|c|c|c|c|c|c|c|c|}
\hline Core & $\begin{array}{l}\text { Top of } \\
\text { Interval } \\
\text { DSF (m) }\end{array}$ & $\begin{array}{l}\text { Bottom of } \\
\text { Interval } \\
\text { DSF }(m)\end{array}$ & $\begin{array}{l}\text { Interval } \\
\text { advanced } \\
\text { (m) }\end{array}$ & $\begin{array}{l}\text { Recovered } \\
\text { length } \\
\text { (m) }\end{array}$ & $\begin{array}{l}\text { Curated } \\
\text { length } \\
\text { (m) }\end{array}$ & $\begin{array}{c}\text { Recovery } \\
\text { (\%) }\end{array}$ & $\begin{array}{c}\text { Date on } \\
\text { deck } \\
(2018)\end{array}$ & $\begin{array}{l}\text { Time on } \\
\text { deck UTC } \\
\text { (h) }\end{array}$ & $\begin{array}{l}\text { Time to } \\
\text { cut core } \\
\text { (min) }\end{array}$ & $\begin{array}{l}\text { Core } \\
\text { barrel }\end{array}$ & $\begin{array}{l}\text { Mud } \\
\text { pumped } \\
\text { (bbl) }\end{array}$ & Driller's notes \\
\hline $5 R$ & 17.9 & 22.6 & 4.7 & 0.13 & 0.15 & 3 & 30 Jun & 0615 & 125 & N-Mag & 30 & \\
\hline $6 \mathrm{R}$ & 22.6 & 27.3 & 4.7 & 0.28 & 0.30 & 6 & 30 Jun & 0855 & 100 & N-Mag & 60 & \\
\hline $7 R$ & 27.3 & 30.5 & 3.2 & 0.23 & 0.26 & 7 & 30 Jun & 1140 & 50 & N-Mag & 90 & \\
\hline $8 \mathrm{R}$ & 30.5 & 34.8 & 4.3 & 0.05 & 0.08 & 1 & 30 Jun & 1420 & 60 & N-Mag & 60 & \\
\hline \multirow[t]{2}{*}{$9 R$} & 34.8 & 39.6 & 4.8 & 0.10 & 0.15 & 2 & 30 Jun & 1930 & 45 & N-Mag & 120 & $\begin{array}{l}\text { Drop and retrieve core barrel; } \\
\text { release bit }\end{array}$ \\
\hline & \multicolumn{2}{|c|}{ Hole U1531E totals: } & 21.7 & 0.79 & 2.70 & 3.6 & & & & & & \\
\hline
\end{tabular}

$4.0 \mathrm{~m}$ (15\%). All cores, penetration depths, core recovery, and times recovered on deck are displayed in Table T1. Drilling conditions were poor and there was high torque, overpull, and frequent stalling of the top drive. The drill string became stuck several times. These conditions forced us to start pulling the drill string out of the hole before Core 3R could be retrieved. After the bit cleared the seafloor at $1420 \mathrm{~h}$ on 23 June 2018, we recovered Core 3R, ending Hole U1531B. The time recorded in Hole U1531B was 14.75 h, or 0.6 days.

\section{Hole U1531C}

With the drill string just above the seafloor, we deployed the subsea camera system, offset the vessel 110 m northeast to the summit of the Lower Cone, and started a seafloor survey at $1730 \mathrm{~h}$ on 23 June 2018 to determine the viability of the drill site and whether or not vent-related animals were present. During the survey, we tagged the seafloor in two locations to verify the exact seafloor depth. We then retrieved the subsea camera system and started coring in Hole U1531C at $1930 \mathrm{~h}$. Cores 376-U1531C-1R through 3R penetrated from the seafloor to $28.4 \mathrm{mbsf}$ and recovered $2.25 \mathrm{~m}$ (8\%). All cores, penetration depths, core recovery, and times recovered on deck are displayed in Table T1. We circulated $30 \mathrm{bbl}$ of high-viscosity mud at several depths to clean the hole. We experienced tight hole conditions throughout coring and faced high torque and frequent overpull, so Hole U1531C was abandoned at 28.4 mbsf. At $0815 \mathrm{~h}$ on 24 June, we started pulling the drill string out of the hole. It cleared the seafloor at $0845 \mathrm{~h}$. We set back the top drive and continued raising the drill string, and the bit arrived at the rig floor at $1340 \mathrm{~h}$, ending Hole U1531C. Inspection of the BHA revealed pronounced abrasion on the outside diameter of the bottom three drill collars and the MBR. In total, 23.5 h, or 1.0 day, was spent in Hole U1531C.

\section{Hole U1531D}

After ending Hole U1531C, we decided to install a reentry system with a short casing string to establish a stable hole in the summit area of the Lower Cone to achieve deeper coring and logging objectives. We made up a drilling BHA (see Figure F5 in the Site U1527 chapter [de Ronde et al., 2019b]) with a 121/4 inch $(\sim 31.1 \mathrm{~cm})$ tricone bit, an $11^{3 / 4}$ inch $(\sim 29.9 \mathrm{~cm})$ underreamer (set to $16^{1 / 2}$ inches, or $\sim 41.9 \mathrm{~cm}$ ), and a mud motor. At $2200 \mathrm{~h}$ on 24 June 2018, we assembled a reentry system with $16 \mathrm{~m}$ of $13 \%$ inch casing, a reentry funnel, and a hard rock landing frame. After the drilling BHA was lowered and attached to the reentry system, we started lowering the entire reentry system to the seafloor at $0500 \mathrm{~h}$ on 25 June. At $0800 \mathrm{~h}$, we deployed the subsea camera and sonar system, continued lowering the drill-in casing assemblage, and picked up the top drive. We started drilling the casing into the seafloor in Hole U1531D at 1030 $\mathrm{h}$ and reached a total depth of $19 \mathrm{mbsf}$ at $1445 \mathrm{~h}$ (Table T1). We then deployed the "go-devil" (an iron weight) to activate the hydraulic release tool (HRT) and release the reentry system. However, we were unable to pull the drilling assembly clear of the casing string because the underreamer arms did not retract completely. We attempted, unsuccessfully, to free the reentry system for $3.5 \mathrm{~h}$; thereafter, we decided to pull the drill string and attached reentry system out of the hole and back to the vessel. After the bit cleared the seafloor at $1835 \mathrm{~h}$, we offset the vessel $400 \mathrm{~m}$ east. We set back the top drive, retrieved the subsea camera and sonar system, and continued raising the drill string. Unfortunately, while we were retrieving the casing and drilling assembly to the surface, the reentry system and casing dropped off the drilling assembly at $2310 \mathrm{~h}$ while picking up the last drill collar and in sight of the moonpool with the doors open. We began taking apart the drilling BHA, and the bit arrived back at the rig floor at $0045 \mathrm{~h}$ on 26 June. In total, $35.0 \mathrm{~h}$, or 1.5 days, was spent in Hole U1531D.

\section{Hole U1531E}

On 26 June 2018, we started making up a new drilling BHA with a $12^{1 / 4}$ inch tricone bit, an $11^{3 / 4}$ inch underreamer (set to $16^{1 / 2}$ inches), and a mud motor to drill $16 \mathrm{~m}$ of $13 \% 3$ inch casing into Hole U1531E, located back on the saddle between the Upper and Lower Cones. After testing the mud motor and underreamer at $0530 \mathrm{~h}$, we had to stop operations for $7 \mathrm{~h}$ because of inclement weather. At $1545 \mathrm{~h}$, we began assembling the casing string, but we had to stop operations once again at $1900 \mathrm{~h}$ because the weather had deteriorated further. The next $24.25 \mathrm{~h}$ was spent waiting for the weather to improve enough to resume operations.

At $1915 \mathrm{~h}$ on 27 June, we continued connecting the drilling BHA (mud motor, underreamer, and drill bit) to the casing string. After welding the casing system, we attached the reentry funnel and hard rock landing skirt. We opened the moonpool doors and started lowering the casing and reentry system to the seafloor at $2350 \mathrm{~h}$. After deploying the subsea camera and sonar system at $0230 \mathrm{~h}$ on 28 June, we continued lowering the casing assembly, picked up the top drive, and positioned the vessel to start drilling. We spudded Hole U1531E at $0705 \mathrm{~h}$, and by $1545 \mathrm{~h}$ we had drilled to $17.9 \mathrm{mbsf}$, working through tight spots. We then deployed the go-devil to activate the HRT to release the drilling assembly from the casing. We were initially not able to retrieve the drilling assembly from the casing string and had to work the drilling assembly to get the underreamer arms to close. After the drill string released from the casing at $1605 \mathrm{~h}$, we raised it above the top of the reentry funnel and observed that the casing had been lifted $4.2 \mathrm{~m}$ while we were trying to release, leaving the base of the casing shoe at 10.7 mbsf. We recovered the subsea camera, set back the top drive, and recovered the drill string to the rig floor. We flushed the mud motor and underreamer with freshwater and disassembled the HRT components and the BHA.

At $0030 \mathrm{~h}$ on 29 June, we began making up the TDCS for running its second test during the expedition. We assembled the TDCS core barrels and BHA, including a 97/8 inch $(\sim 25.1 \mathrm{~cm})$ poly- 
crystalline diamond compact (PDC) bit. We started lowering the TDCS BHA to the seafloor at $0530 \mathrm{~h}$, deployed the subsea camera and sonar system, and picked up the top drive. We then reconfigured the TDCS core barrels and conducted a "drop test" deployment (i.e., dropped the core barrel through the end of the drill string and retrieved it prior to reentry). We reentered Hole U1531E at $1347 \mathrm{~h}$, lowered the drill string to $\sim 8 \mathrm{mbsf}$, and flushed the interior of the casing. While recovering the subsea camera, we checked for debris fill below the end of the casing at $10.7 \mathrm{mbsf}$. At $1430 \mathrm{~h}$, we deployed a TDCS core barrel, washed down to the bottom of the hole at 17.9 mbsf, flushed the hole with two back-to-back high-viscosity mud sweeps, and retrieved the TDCS core barrel (Core 376U1531E-2G; $0.5 \mathrm{~m}$ of fresh dacite pebbles). The next TDCS barrel got stuck in the BHA and could not be recovered after three attempts. We terminated the TDCS test and started pulling the drill string out of the hole. It cleared the seafloor at $2045 \mathrm{~h}$. We set back the top drive and recovered the drill string, and the bit arrived back on the rig floor at $0110 \mathrm{~h}$ on 30 June.

We then made up an RCB BHA (see Figure F4 in the Site U1527 chapter [de Ronde et al., 2019b]) and started lowering it to the seafloor. We deployed the subsea camera and sonar system to aid in reentry of Hole U1531E. We continued lowering the drill string, picked up the top drive, and reentered Hole U1531E at $1133 \mathrm{~h}$ on 30 June. After recovering the subsea camera, we reassembled the rig floor, pumped $40 \mathrm{bbl}$ of high-viscosity mud to clean the hole, and lowered the bit until it encountered hard debris fill at 9 mbsf (inside the casing). At $1245 \mathrm{~h}$, we dropped an RCB core barrel and washed back to the bottom of the hole at 17.9 mbsf (Core 376-U1531E-4G; $0.15 \mathrm{~m}$ of dacitic lapilli). We then cut half-length (4.8 $\mathrm{m}$ advances) Cores 5R-9R from 17.9 to $39.6 \mathrm{mbsf}$ and recovered $0.8 \mathrm{~m} \mathrm{(4 \% ).} \mathrm{We}$ had to pump multiple high-viscosity mud sweeps to keep the bottom of the hole clean to be able to keep coring. Hole conditions were poor. After recovering Core 9R, the top drive blower motor seized with a bad bearing. We began repairs ( $4.75 \mathrm{~h}$ of downtime) while evaluating repair time versus remaining coring time. We decided to conclude coring activities and undertake other operations. We released the bit in Hole U1531E and shifted the circulating sleeve back into the circulating position. After releasing the bit, we pulled the drill string out of the hole with the top drive installed, clearing the seafloor and ending coring operations in Hole U1531E at $1435 \mathrm{~h}$ on 1 July. All cores, penetration depths, core recovery, and times recovered on deck are displayed in Table T1.

We left Hole U1531E and transited to Hole U1528D for fluid sampling and temperature measurements. After completing operations in Hole U1528D, we returned to Hole U1531E at $0745 \mathrm{~h}$ on 2 July. We lowered the drill string with the top drive installed and reentered Hole U1531E at $1015 \mathrm{~h}$. We lowered the ETBS memory tool into the hole with the core line for a temperature profile. After completing the ETBS tool run, which yielded a stationary temperature measurement of $5^{\circ} \mathrm{C}$ at $20 \mathrm{mbsf}$, we pulled the drill string out of the hole and cleared the seafloor at $1135 \mathrm{~h}$. The drill string was pulled back to $1149 \mathrm{~m}$ water depth with the top drive installed. We began the transit back to Hole U1528D, ending Hole U1531E at $1330 \mathrm{~h}$. In total, $139.5 \mathrm{~h}$, or 5.8 days, was spent in Hole U1531E.

\section{Igneous petrology and volcanology}

At Site U1531, one igneous unit was recovered from four holes located at the Lower Cone (Figure F2). Igneous Unit 1 consists of plagioclase-pyroxene-phyric dacite lava recovered from Sections 376-U1531A-1R-1 (0-1.14 mbsf); 376-U1531B-1R-1 through 2R-1
Figure F2. Lithostratigraphic summary, Holes U1531A-U1531C and U1531E.

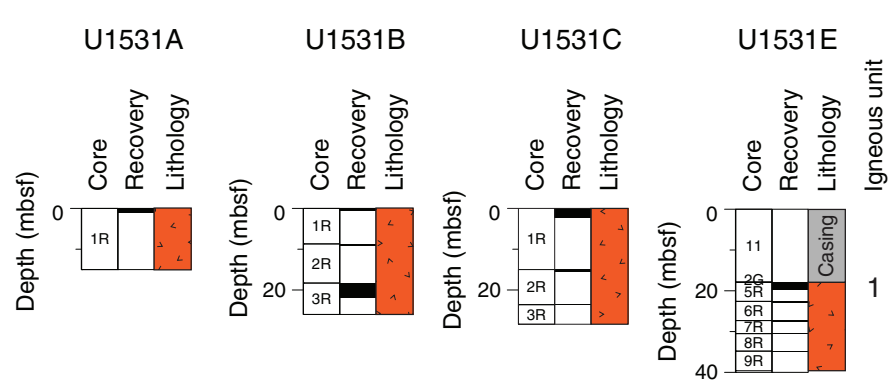

Young volcanics

Massive lava and tephra

(0-9.12 mbsf) and 3R-2 (96-108 cm; 20.23-20.35 mbsf); 376U1531C-1R-1 through 3R-1 (0-23.75 mbsf); and 376-U1531E-5R-1 through 9R-1 (17.90-34.95 mbsf). Dacitic ash, ash with lapilli, and lapilli tephra with ash was recovered from Sections 376-U1531B3R-1 through 3R-CC (18.3-21.97 mbsf). Igneous Unit 1 was also recovered from Hole U1531E in three ghost cores (i.e., cores without depth advance) in the form of subangular pebble-sized fragments of plagioclase-pyroxene-phyric dacite lava in Sections 2G-1, 3G-2 $(18-26 \mathrm{~cm})$, and 4G-1 and dacitic lapilli-ash and lapilli-tephra in interval $3 \mathrm{G}-1,0 \mathrm{~cm}$, to $3 \mathrm{G}-2,18 \mathrm{~cm}$.

\section{Igneous Unit 1}

Intervals: 376-U1531A-1R-1, 0-114 cm; 376-U1531B-1R-1, 0 $\mathrm{cm}$, to 3R-CC, $22 \mathrm{~cm}$; 376-U1531C-1R-1, $0 \mathrm{~cm}$, to 3R-1, 15 $\mathrm{cm}$; 376-U1531E-2G-1, $0 \mathrm{~cm}$, to 4G-1, $16 \mathrm{~cm}$, and 5R-1, 0 $\mathrm{cm}$, to $9 \mathrm{R}-1,15 \mathrm{~cm}$

Depths: Hole U1531A $=0-1.14$ mbsf; Hole U1531B $=0-21.97$ mbsf; Hole U1531C $=0-23.75$ mbsf; Hole U1531E $=17.90-$ $34.95 \mathrm{mbsf}$

Lithology: plagioclase-pyroxene-phyric dacite lava and dacitic ash, ash with lapilli, and lapilli tephra with ash

Igneous Unit 1 consists of unaltered to slightly altered plagioclase-pyroxene-phyric dacite lava and dacitic ash, ash with lapilli, and lapilli tephra with ash. The dacite lava makes up all of Holes U1531A and U1531C and the stratigraphically upper part of Hole U1531B, where it is underlain by unconsolidated tephra from Core 376-U1531B-3R downhole. Thereafter, lava reoccurs intercalated in interval 3R-2, 96-108 cm. Fragments of dacite lava were also recovered in Sections 376-U1531E-2G-1, 3G-1, 3G-2, and 4G-1 without stratigraphic context and in Sections 5R-1 through 9R-1.

Macroscopic evaluation of the lava shows that it is a black to very dark bluish gray to very dark gray porphyritic and glomeroporphyritic plagioclase-pyroxene-phyric dacite (Figure F3). Euhedral plagioclase makes up 2-10 vol\% of the rock and occurs as both phenocrysts and glomerocrysts as long as $1.5-2.0 \mathrm{~mm}$ (average $=$ $0.5-1.0 \mathrm{~mm}$ ). Subhedral pyroxene generally occurs with the plagioclase glomerocrysts; it is less abundant than plagioclase (1-2 vol\%) and has a maximum size of $0.5-1.0 \mathrm{~mm}$ (average $=0.2-0.5$ $\mathrm{mm}$ ). The samples have massive cryptocrystalline to microcrystalline groundmasses, although many have flow fabrics defined by elongated vesicles. Additionally, the samples often exhibit quenched glassy surfaces on vesicle walls or the sample surface. The samples are moderately to highly vesicular and have maximum vesicle diameters of $2-10 \mathrm{~mm}$ (average $=0.1-4 \mathrm{~mm}$ ). Vesicles are sub- 
Figure F3. Representative macroscopic images of Igneous Unit 1, Hole U1531B. A. Vesicular, glassy lava with visible plagioclase phenocrysts. B. Hybrid of effusive and clastic eruptive styles, with lava fragments (example of clast indicated by yellow dashed circle) enclosed in a glassy matrix.
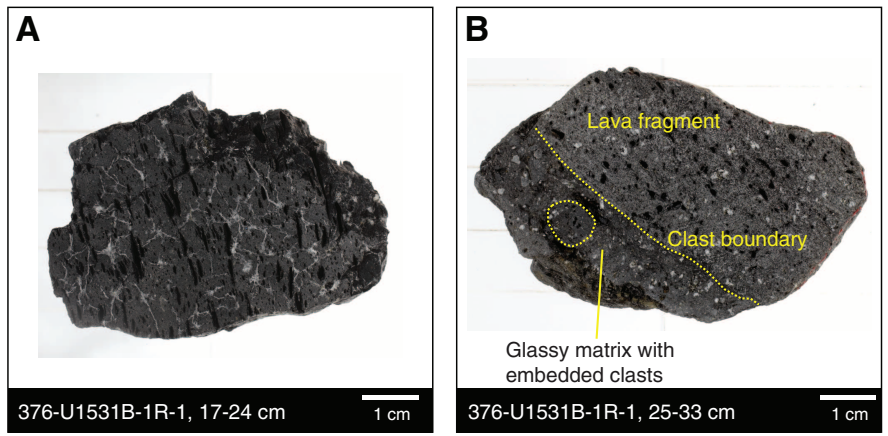

rounded to rounded and elongated. The overall appearance of the samples varies between very dark with glassy exteriors to slightly muted gray, which is possibly a result of higher abundance of microlite crystals caused by slightly slower cooling.

Microscopic observations indicate a primary mineral assemblage of plagioclase and clinopyroxene $\pm \mathrm{Fe}$-Ti oxides in the groundmass. The groundmass consists of unaltered to partially altered dark brown glass with $30-75 \mathrm{vol} \%$ bimodal to seriate plagioclase microlites with a trachytic texture. The lava is moderately vesicular and ranges from 5 to $20 \mathrm{vol} \%$ in the two thin sections examined (376-U1531A-1R-1, 72-74 cm [TS 121], and 1R-2, 55-57 cm [TS 124]). Typically, vesicles are rounded to subangular and elongate and range widely in size from 0.05 to $8 \mathrm{~mm}$ in individual thin sections, the same range noted during the macroscopic observations. Plagioclase, orthopyroxene, clinopyroxene, accessory Fe-Ti oxide, and sulfide minerals possibly of magmatic origin were observed as phenocrysts and in plagioclase-pyroxene-Fe-Ti oxide glomerocrysts (Figure F4A). Plagioclase phenocrysts constitute 7-20 vol\% of the lava. They are as large as $1.5 \mathrm{~mm}$ but are typically in the $0.1-0.5 \mathrm{~mm}$ size range and often have oscillatory zoning (Figure F4B). Some plagioclase phenocrysts host brown glassy silicate melt inclusions and mineral inclusions (e.g., apatite and Fe-Ti oxide) (Figure F4C, F4D). Euhedral orthopyroxene and clinopyroxene phenocrysts comprise $<5$ vol\% of the rock (Figure F4E). They are as large as $1 \mathrm{~mm}$ (average $=0.05-0.30 \mathrm{~mm}$ ) and contain rare silicate melt inclusions. A resorbed clinopyroxene was observed in Sample 376-U1531C-1R-2, $55-57 \mathrm{~cm}$ (TS 124). Equant Fe-Ti oxides and trace magmatic sulfides are present in each sample. Sample 376-U1531A-1R-1, 72-74 cm (TS 121), includes evidence for Fe-Ti oxides nucleating at and growing from the rim of a magmatic sulfide droplet (Figure F4F). Glomerocrysts and groundmass are cut by fine fractures radiating from vesicles. These fractures contain a second generation of trace sulfides. Also observed entrained in the dacite lava in Sample 1R-1, 72-74 cm (TS 121) (Figure F5A), are several clasts that are unaltered and dacitic but do not have glass in the groundmass. Similar textures of an exclusively microlitic groundmass are present at one rim and as streaks or deformed clasts.

Pyroclastic material was recovered from Hole U1531B in intervals $3 R-1,0 \mathrm{~cm}$, to $3 \mathrm{R}-2,96 \mathrm{~cm}(18.3-20.23 \mathrm{mbsf})$, and $3 \mathrm{R}-3,0 \mathrm{~cm}$, to $3 \mathrm{R}-\mathrm{CC}, 22 \mathrm{~cm}(20.35-21.97 \mathrm{mbsf})$, and from Hole U1531E in Section 3G-1 and interval 3G-2, 0-18 cm. The material consists of mostly unaltered, black to greenish black polymict dacitic ash, ash with lapilli, and lapilli tephra with ash. The tephra is moderately to well sorted and exhibits normal grading, which is most likely drill-
Figure F4. Petrological features observed in thin sections of Igneous Unit 1, Holes U1531A-U1531C. A. Plagioclase (Plag)-clinopyroxene (Cpx) glomerocryst. Opx $=$ orthopyroxene (cross-polarized light [XPL]). B. Plagioclase with oscillatory zoning (XPL). C. Melt inclusion (MI) and embayment in plagioclase (plane-polarized light [PPL]). D. Apatite and magnetite (Mgt) enclosed in plagioclase (PPL). E. Ortho- and clinopyroxenes intergrown with magnetite (XPL). F. Magnetite and sulfide (Sulf) inclusion (reflected light [Refl.]).
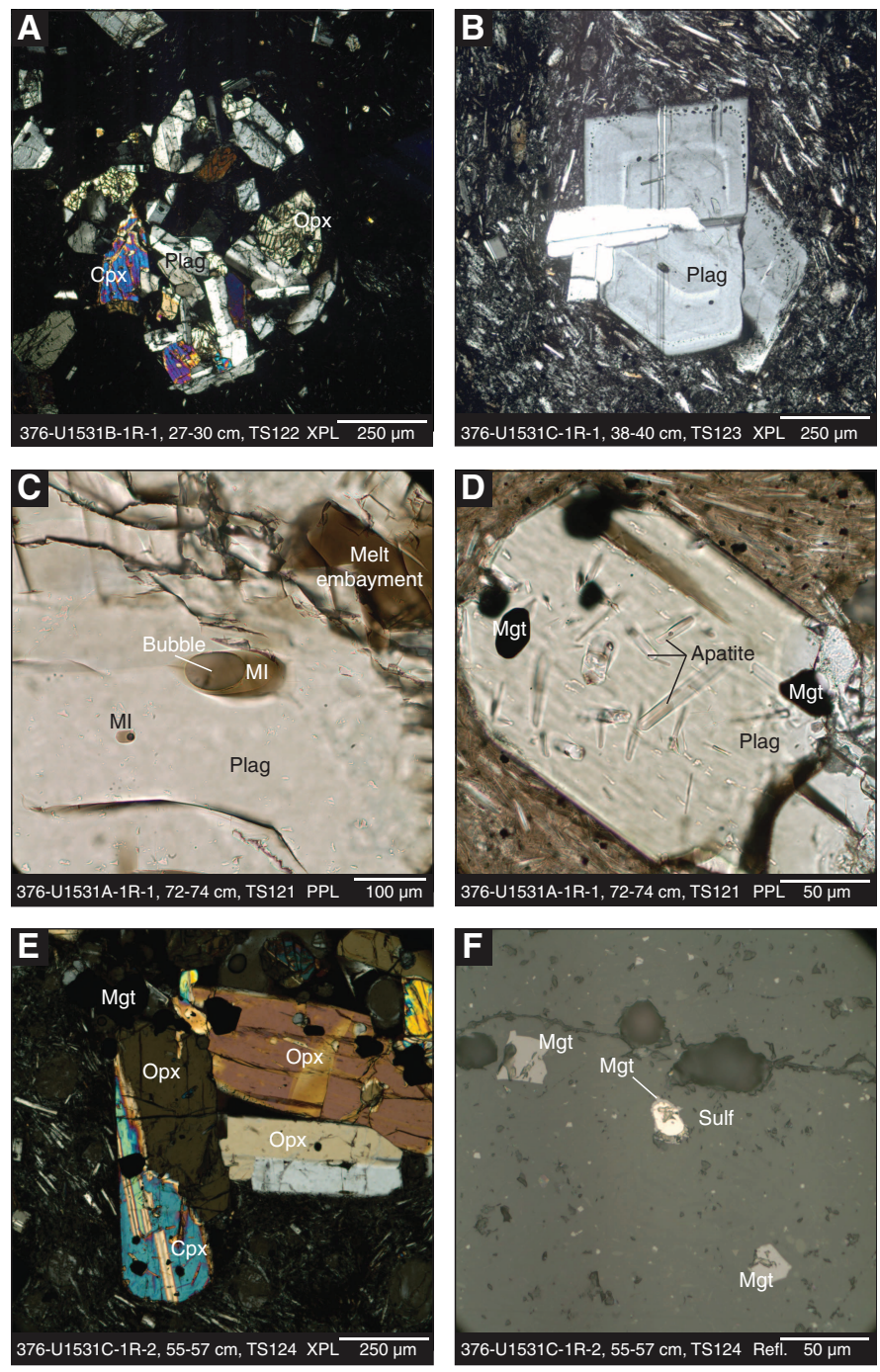

ing induced. Average grain sizes range between ash and medium lapilli, whereas individual clasts reach coarse lapilli sizes. The lapilli are angular to subangular and are likely fragments of moderately vesicular plagioclase-phyric dacite lava. Section 376-U1531B-3R-3 also contains lapilli-sized lithic fragments consisting of altered volcaniclastic material. The ash fraction of the intervals contains vitric (65 vol\%), crystal (30 vol\%), and lithic (5 vol\%) components. Smear slide analysis confirms that the vitric components are angular fragments of microlite-bearing dacite lava. No vesicles were observed in these samples, although some fragments might be broken along vesicle walls. Minor amounts of angular, brown glass shards without microlites were also observed $(<1$ vol\%). Angular crystal fragments of plagioclase (25 vol\%) and pyroxene (5 vol\%) make up the crystal fraction, whereas angular altered volcaniclastics of various colors (i.e., different shades of gray and brown) form the lithic components. 
Figure F5. Representative microscopic images of textural features in thin sections of Igneous Unit 1, Holes U1531A and U1531B (PPL). A. Clast and lighter rim showing an exclusively microlitic groundmass. B. Dominant clast type with spherical, rounded vesicles and an irregular, probably quenched margin embedded in glassy matrix. Mgt = magnetite, Plag = plagioclase . C. Different clasts embedded in glassy matrix with flow texture. D. Second clast type with irregular vesicles embedded in glassy matrix.
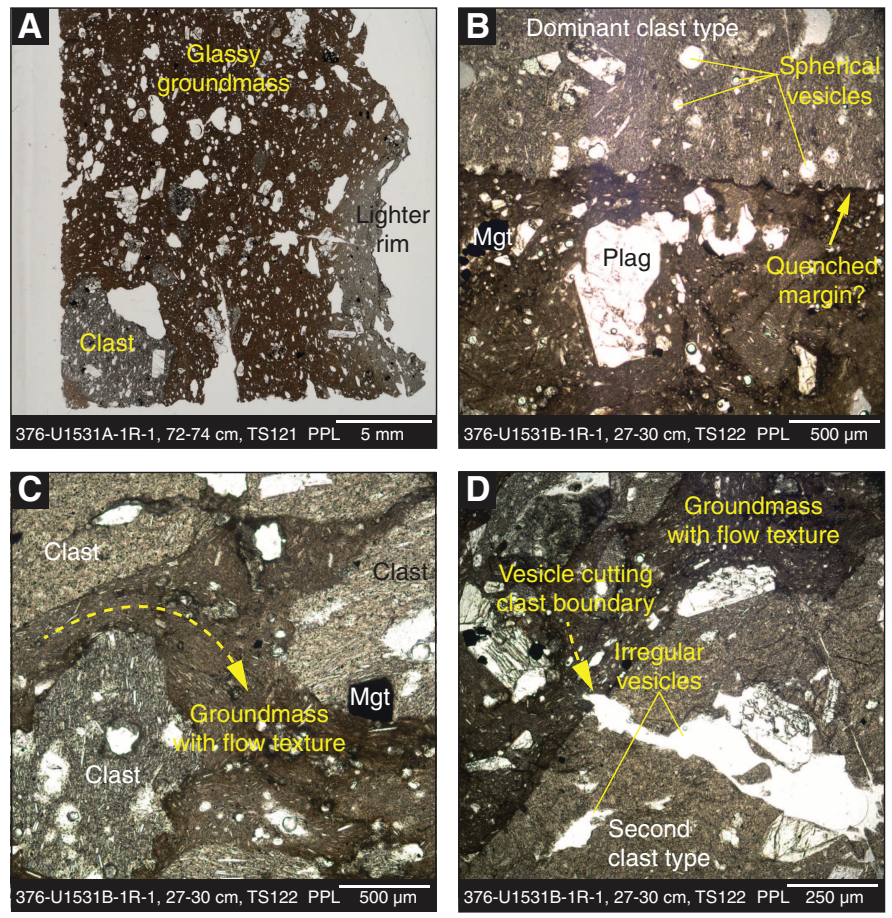

One piece of dacite lava in interval 376-U1531B-1R-1, 25-33 $\mathrm{cm}$, has a visibly more clastic appearance relative to the adjacent over- and underlying intervals (Figure F3B). The piece consists of a coarse lapilli-sized fragment of vesicular plagioclase-pyroxenephyric lava welded with a darker, sparsely vesicular glassy matrix. Also embedded into this glassy matrix are rounded, fine lapillisized volcanic clasts of different colors (i.e., shades of gray and brown) and vesicularity and ash-sized plagioclase crystals. The interval is therefore described as polymict lapilli-tuff, although the character of the rock is transitional between pyroclastic and effusive. Microscopic observation (interval 1R-1, 27-30 cm; TS 122) confirms that this polymict lapilli-tuff indeed contains two clast types, both of which may represent juvenile components (Figure F5B, F5D). Both clast types consist of plagioclase-pyroxeneglomeroporphyritic dacite similar to that found in the more coherent units. The dominant clast type occurs only as lapilli-sized fragments and has a higher content of plagioclase microlites of $\sim 40 \mathrm{vol} \%$ with $\sim 15$ vol\% rounded and spherical vesicles (Figure F5B). The clasts of the second type contain $\sim 30 \mathrm{vol} \%$ microlites and are either nonvesicular (smaller fragments) or contain 20 vol\% (larger fragments) of subrounded, highly irregular vesicles that can cut boundaries between clasts and matrix (Figure F5D). Clasts of this type are ash to fine lapilli sized. Both clast types have irregular, possibly quenched margins (Figure F5B), and all clastic components are welded together, either contacting each other directly or by means of the surrounding coherent glassy matrix. The matrix locally exhibits aligned microlites suggestive of a flow texture (Figure F5C).

\section{Interpretation}

The dacite lava from Site U1531 has very similar major and trace element compositions to the volcanic materials recovered at Sites U1527-U1529 (see portable X-ray fluorescence [pXRF] results; $N=6$; Table T4). Decimeter-scale intercalation of tephra and lava deposits together with drilling disturbance hinders our ability to estimate stratigraphic thickness or relationships. However, petrographic observations provide some important constraints on the evolution of the Brothers volcano magmatic system and subsequent eruptive processes. Although orthopyroxene and clinopyroxene coexist in Site U1531 dacites, hornblende was observed in many samples volcano-wide, which indicates relatively low magmatic $\mathrm{H}_{2} \mathrm{O}$ contents (cf. 2-4 wt\% $\mathrm{H}_{2} \mathrm{O}$ in Keith et al., 2018). Resorbed cores in plagioclase (see Igneous petrology and volcanology in the Site U1527 chapter [de Ronde et al., 2019b]), resorption of clinopyroxene, breakdown of an olivine xenocryst to form a symplectite of magnetite and orthoproxene (see Igneous petrology and volcanology in the Site U1529 chapter [de Ronde et al., 2019d]), and more coarse-grained aggregates ( 1-2 mm) of plagioclase, clinopyroxene, and Fe-Ti oxide indicate mixing of a more mafic with a more silicic magma to produce the Brothers volcano dacite, which is consistent with observations of dacite from other volcanic arc systems (e.g., Grove et al., 2005; Millet et al., 2014).

In addition to the general discussion outlined in Igneous petrology and volcanology in the Site U1529 chapter (de Ronde et al., 2019d) on possible fragmentation processes affecting the young volcanics at Brothers volcano, Site U1531 provides further constraints on eruptive style, fragmentation, and emplacement processes. The ash, ash with lapilli, and lapilli tephra with ash may have been produced by rapid, high-energy eruptions that resulted in higher degrees of fragmentation compared with more coherent dacite lava (e.g., Fisher and Schmincke, 1984). In contrast, the lava at the Lower Cone formed during more effusive dominated phases of volcanism, where the melt was either quenched in contact with seawater to produce dacite with a glassy groundmass (i.e., its black appearance) or cooled slightly slower when sealed from direct contact with seawater, resulting in a microcrystalline groundmass (i.e., dark gray appearance). The stratigraphic relationship between the unconsolidated volcaniclastic material and coherent dacite lava, however, is unclear, making it impossible to determine whether the two eruptive styles alternated or occurred simultaneously.

Low-energy effusive extrusion of lava into seawater can be associated with synchronous or subsequent fragmentation caused by quench fragmentation (i.e., forming hyaloclastite deposits, thermal contraction fracturing, and/or partial collapse of lava formations triggered by replenishing melt and/or magmatic degassing). Sample 376-U1531B-1R-1, 25-33 cm (Figure F3B), possibly records the entrainment and welding of such fragments in subsequent extruding liquid lava, resulting in a hyaloclastite-lava flow hybrid. Even though they are quenched on their exterior, the fragments were still liquid and degassing on their interior when entrained by the lava, as recorded by vesicles cutting clast/matrix boundaries. In thin section, the textures of Sample 1R-1, 25-33 cm (TS 122), resemble those of the altered volcaniclastic units recovered at Sites U1527, U1528, and U1530 (see Igneous petrology and volcanology in the Site U1527 chapter, Igneous petrology and volcanology in the Site U1528 chapter, and Igneous petrology and volcanology in the Site U1530 chapter [de Ronde et al., 2019b, 2019c, 2019e]) and 
might therefore represent an example of the unaltered protolith for these lithologies. However, Sample $1 \mathrm{R}-1,25-33 \mathrm{~cm}$, is unique among lithologies recovered during Expedition 376; therefore, we cannot assess whether it is sufficiently representative for eruption styles at Brothers volcano. The altered volcaniclastic units at Brothers volcano can accumulate to $>200 \mathrm{~m}$ thickness (see Igneous petrology and volcanology in the Site U1530 chapter [de Ronde et al., 2019e]); thus, it is uncertain whether the above described process of a hyaloclastite-lava flow hybrid can produce the required deposit volumes.

\section{Alteration}

The volcanic rocks of Igneous Unit 1 at Site U1531 appear unaltered to slightly altered. Alteration Type I is the only alteration type recognized at this site, and it is defined by the presence of smectite and Fe oxyhydroxide, the two primary alteration minerals identified in these rocks. The Alteration Type I depth interval shown below is

Table T2. Alteration Type I interval depths, Holes U1531A-U1531C and U1531E. Download table in CSV format.

\begin{tabular}{ccccc}
\hline Hole & $\begin{array}{c}\text { Top } \\
\text { core }\end{array}$ & $\begin{array}{c}\text { Bottom } \\
\text { core }\end{array}$ & $\begin{array}{c}\text { Top depth } \\
\text { (mbsf) }\end{array}$ & $\begin{array}{c}\text { Bottom depth } \\
\text { (mbsf) }\end{array}$ \\
\hline U1530A & 1R & $1 R$ & 0.0 & 1.1 \\
U1530B & $1 R$ & $3 R$ & 0.0 & 22.0 \\
U1530C & $1 R$ & $3 R$ & 0.0 & 23.8 \\
U1530E & $5 R$ & $9 R$ & 17.9 & 39.6 \\
\hline
\end{tabular}

a representative example. All identified intervals for Alteration Type I are summarized in Table $\mathbf{T} 2$.

\section{Alteration Type I}

Distinguishing alteration minerals: Fe oxyhydroxides \pm smectite \pm zeolite \pm pyrite

Degree of alteration: slightly altered

Interval: 376-U1531A-1R-1, $0 \mathrm{~cm}$, to $1 \mathrm{R}-1,100 \mathrm{~cm}$

Depth: 0.00-1.14 mbsf

The volcanic rocks of Alteration Type I are unaltered to slightly altered (see Table T7 in the Expedition 376 methods chapter [de Ronde et al., 2019a]; Figure F6). The alteration mineral assemblage consists of smectite (identified by XRD analysis; Table T3) and Fe oxyhydroxides (identified visually) with minor zeolite (observed macroscopically). The unaltered fragments are dark gray, and the slightly altered fragments are lighter gray. Vesicles are locally lined or partially infilled with Fe oxyhydroxide, a light gray clay mineral (likely smectite), zeolite, and/or pyrite (Figure F6). In Section 376-U1531C-1R-2, one vug is filled with very fine grained framboidal pyrite overgrown by tabular-shaped transparent (unidentified) zeolite crystals (Figure F6C). Microscopically, the light gray areas have been partly replaced by acicular-shaped clay minerals. In contrast, darker fragments retain their glassy texture. Plagioclase and clinopyroxene phenocrysts and microlitic texture are preserved in unaltered samples but may locally be replaced by brown acicular palagonite (?) that is also seen infilling voids in slightly altered samples. In Section 376-U1531A-1R-1, a 1 cm wide, light gray clast partially replaced by acicular-shaped clay minerals is contained in unaltered volcanic rock.

Figure F6. Slightly altered volcanic rock, Hole U1531A. A. Native sulfur coats and fills voids together with a light gray clay mineral. B. Fe oxyhydroxide coating a vug with zeolite crystals. C. Fine-grained spherical pyrite grain aggregate with tabular-shaped (unidentified) zeolite crystals in a vug.
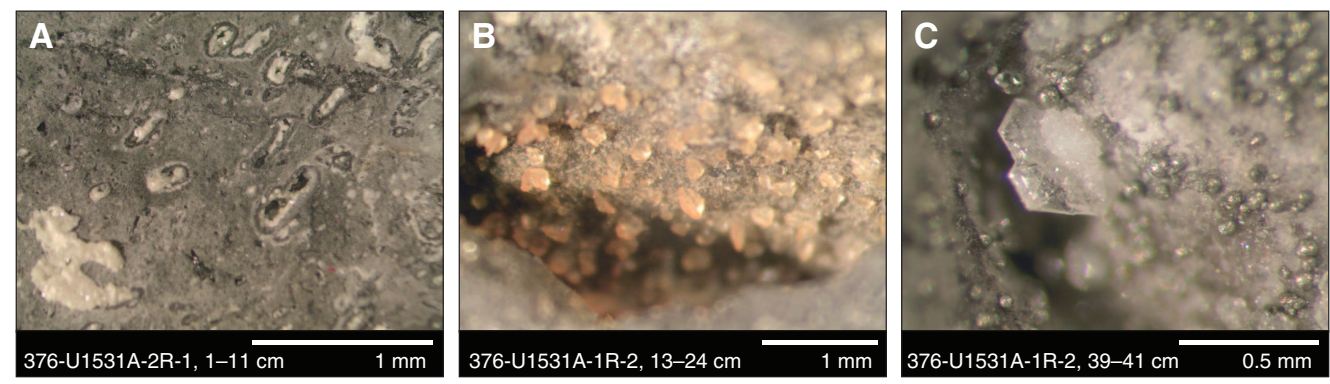

Table T3. Constituent minerals identified by X-ray diffraction analysis, Holes U1531B and U1531C. X indicates qualitative abundance of each mineral relative to the total range of abundances of each mineral within the sample set. Download table in CSV format.

\begin{tabular}{|c|c|c|c|c|c|c|c|c|c|}
\hline $\begin{array}{l}\text { Core, section, } \\
\text { interval }(\mathrm{cm})\end{array}$ & $\begin{array}{c}\text { Top } \\
\text { depth } \\
\text { (mbsf) }\end{array}$ & $\begin{array}{c}\text { Bottom } \\
\text { depth } \\
\text { (mbsf) }\end{array}$ & $\begin{array}{l}\text { Degree of } \\
\text { alteration }\end{array}$ & $\begin{array}{c}\text { Degree of } \\
\text { alteration } \\
\text { rank }\end{array}$ & $\begin{array}{l}\text { Alteration } \\
\text { type }\end{array}$ & Smectite & Plagioclase & Clinopyroxene & Orthopyroxene \\
\hline \multicolumn{10}{|l|}{ 376-U1531B- } \\
\hline 3R-CC, 11-12 & 21.86 & 21.87 & Slightly altered & 1 & 1 & $x$ & $x$ & $x$ & $x$ \\
\hline \multicolumn{10}{|l|}{ 376-U1531C- } \\
\hline $1 \mathrm{R}-1,38-40$ & 0.36 & 0.38 & Slightly altered & 1 & 1 & & $x$ & $x$ & $x$ \\
\hline $1 R-2,55-57$ & 1.96 & 1.98 & Slightly altered & 1 & 1 & & $\mathrm{x}$ & $x$ & $\mathrm{x}$ \\
\hline
\end{tabular}


The occurrence of Fe oxyhydroxides, smectite, and minor pyrite and the preservation of primary igneous minerals and textures at Site U1531 suggests alteration of volcanic rocks under ambient seawater conditions.

\section{Structural geology Igneous Unit 1}

Site U1531 has revealed a structural record of volcanic eruptions and brittle deformation in all holes (U1531A-U1531C and U1531E). All structures were recorded in the Structure and Vein_fracture_density tabs in the DESClogik macroscopic workbook (see DESC_WKB in Supplementary material).

\section{Volcanic structures}

All Site U1531 holes have volcanic fabrics of varying intensity. Volcanic fabrics are defined by elongated vesicles, plagioclase microlites, and to a lesser extent plagioclase and pyroxene phenocrysts and glomerocrysts (Figure F7). Volcanic fabric intensity ranges from isotropic to strong with the majority of intervals having a strong fabric. Isotropic rocks are present in intervals 376-U1531B3R-3, 0-50 cm (20.35-20.85 mbsf), and 376-U1531C-2R-1, 38-46

Figure F7. Volcanic fabrics, Holes U1531B and U1531C. A. Subvertical volcanic fabric defined by elongate vesicles. B. Moderately dipping volcanic fabric defined by foliation and lineation. Aspect ratio of vesicles is $\leq 15$. C. Moderate volcanic fabric defined by elongate vesicles, plagioclase microlites, and to a lesser extent plagioclase phenocrysts (PPL). Sample is unoriented. D. Volcanic clasts with volcanic fabrics (white arrows) (PPL). Orientation of each fabric is distinct from fabrics in other clasts. Lower part of image is an isotropic to weak volcanic fabric. Sample is unoriented.
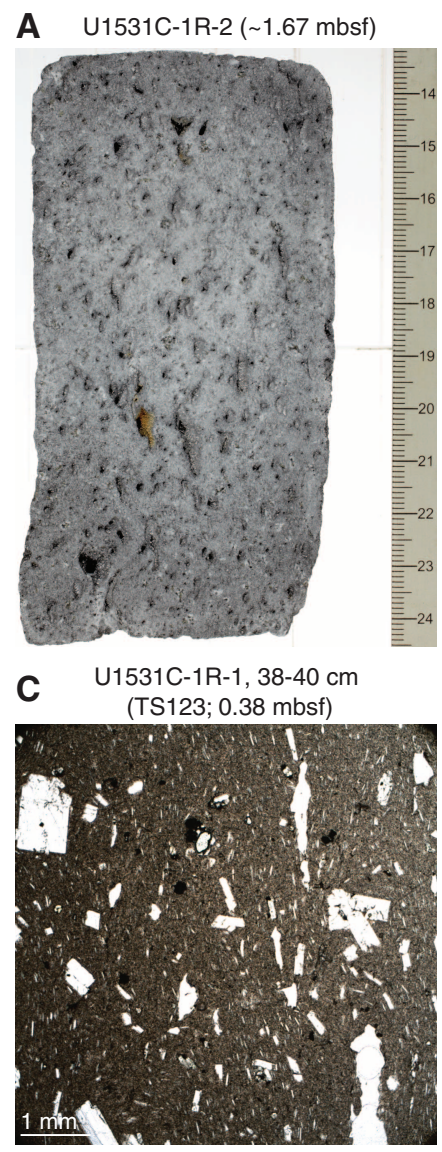

\section{B U1531C-2R-1 ( 15.1 mbsf)}

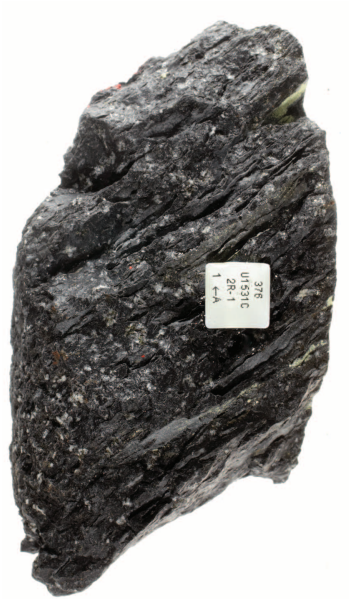

U1531B-1R-1, 27-30 cm (TS122; $0.27 \mathrm{mbsf}$ )

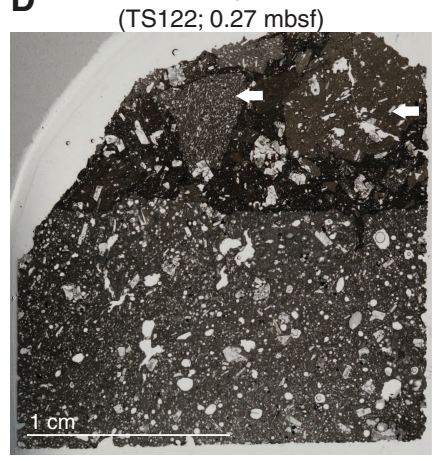

$\mathrm{cm}$ (15.38-15.46 mbsf). All other intervals have moderate to strong fabrics, and some vesicles have aspect ratios as high as 15 . Volcanic fabrics defined by vesicles can have foliation and/or lineation. No orientation measurements of fabrics could be made in Hole U1531A, only one measurement could be made in Hole U1531B, several measurements were made in Hole U1531C, and no measurements were made in Hole U1531E. Fabric dip ranges from $39^{\circ}$ to $89^{\circ}$ with an average of $71^{\circ}$. In Hole U1531E from 0 to $2.35 \mathrm{mbsf}$, fabric dip varies in a very regular pattern from steep $\left(89^{\circ}\right)$ at the bottom of this interval to moderate $\left(58^{\circ}\right)$ at the top.

Interval 376-U1531A-1R-1, 69-74 cm, is dacite with clasts (see Igneous petrology and volcanology) and was observed microscopically in Sample 1R-1, 38-40 cm (TS 123; 0.38 mbsf) (Figure F7C). The host dacite lava has a volcanic fabric defined by elongate vesicles and plagioclase microlites. Each clast has a volcanic fabric defined by different percentages of plagioclase microlites, and each fabric in the clasts has a distinct orientation. The presence of distinctly oriented volcanic fabrics in clasts is similar to the volcanic fabric relations seen in lapilli tuffs from other sites around Brothers volcano (see Structural geology in the Site U1527 chapter, Structural geology in the Site U1528 chapter, and Structural geology in the Site U1530 chapter [de Ronde et al., 2019b, 2019c, 2019e]).

A few intervals in Hole U1531C have lineations defined by elongate vesicles: $1 \mathrm{R}-1,86-97 \mathrm{~cm}(0.86-0.97 \mathrm{mbsf}) ; 1 \mathrm{R}-1,124-137 \mathrm{~cm}$ (1.24-1.37 mbsf); 1R-2, 12-25 cm (1.55-1.68 mbsf); and 2R-1, 0-11 $\mathrm{cm}$ (15-15.2 mbsf). All lineations have moderate to steep plunges subparallel to dip.

\section{Fractures}

Two types of fractures were observed at Site U1531: microfractures and discrete fractures. Microfractures were observed in all holes and are most apparent on cut surfaces. Microfractures are difficult to distinguish; however, minute delicate precipitates of halite and gypsum (from seawater) delineated microfractures once pieces were cut and dried, providing a stark contrast between the black dacite and the white precipitate. These intervals are logged as having minor brittle deformation (see Brittle deformation in the Expedition 376 methods chapter [de Ronde et al., 2019a]).

Discrete fractures are most apparent in Hole U1531C where six discrete fractures were measured. Fracture dip ranges from $18^{\circ}$ to $85^{\circ}$ with an average of $59^{\circ}$. Fracture walls are typically lighter in color than groundmass and are partially covered by secondary minerals. Alteration phases along fractures include native sulfur and Fe oxyhydroxides.

\section{Geochemistry \\ Hard rock geochemistry}

A set of six samples was selected for shipboard geochemical analysis of major and trace element compositions (Tables T4, T5). All samples are from Igneous Unit 1, which consists of plagioclasepyroxene-phyric dacite lava as well as unconsolidated ash, ash with lapilli, and lapilli tephra (see Igneous petrology and volcanology). Samples span the depth ranges of Holes U1531A-U1531C and

Table T4. Rock powder portable X-ray fluorescence analyses results, Holes U1531A-U1531C and U1531E. Download table in CSV format.

Table T5. Major and trace element abundances of rock powders determined by inductively coupled plasma-atomic emission spectroscopy, Holes U1531A-U1531C and U1531E. Download table in CSV format. 
U1531E from 0.36 mbsf (Sample 376-U1531C-1R-1, 38-40 cm) to 21.86 mbsf (Sample 376-U1531B-3R-CC, 11-12 cm). Samples were chosen from each hole: one from Hole U1531A, two from Hole U1531B, two from Hole U1531C, and one from Hole U1531E.

\section{Igneous geochemistry}

Unaltered to slightly altered dacite lava and tephra at Site U1531 (Igneous Unit 1) have typical dacite compositions with $\mathrm{SiO}_{2}$ contents ranging from 62.3 to $65.0 \mathrm{wt} \%$ and $\mathrm{Na}_{2} \mathrm{O}+\mathrm{K}_{2} \mathrm{O}$ contents ranging from 6.5 to $6.9 \mathrm{wt} \%$ (Tables T4, T5; Figure F8). The similarity of major elements in unaltered and slightly altered dacites from Sites U1527, U1529, and U1531 are consistent with the low compositional range previously observed in dacite at Brothers volcano (Wright and Gamble, 1999; Haase et al., 2006; Timm et al., 2012; Graham et al., 2008). Average compositions of dacitic samples from Site U1531 are reported in Table T5 and are compared with average compositions of unaltered to slightly altered volcanoclastic materials and lava from Igneous Unit 1 in Hole U1527A and from Site U1529. For all major elements and most trace elements, geochemical compositions of fresh dacite in Holes U1529A, U1529B, and U1531A-U1531C are indistinguishable from each other (i.e., within $5 \%$ difference). Sample 376-U1531E-3G-1, 120-121 cm, is, however, slightly depleted in $\mathrm{MgO}, \mathrm{CaO}, \mathrm{Al}_{2} \mathrm{O}_{3}$, and $\mathrm{Fe}_{2} \mathrm{O}_{3}$, suggesting a different extent of fractional crystallization (i.e., plagioclase-pyroxene).

\section{Volatile geochemistry}

The five powdered samples of plagioclase-pyroxene phyric dacite lava and lapilli collected from Holes U1531A-U1531C for inductively coupled plasma-atomic emission spectroscopy (ICP-AES) analysis were also analyzed for TC, total nitrogen (TN), and total sulfur contents using the elemental analyzer (Table T6). TC content is low $(<250 \mu \mathrm{g} / \mathrm{g})$ except for one sample from Hole U1531C (376U1531C-1R-1, 38-40 cm) that has high TC $(1901 \mu \mathrm{g} / \mathrm{g})$. Total sulfur content averages $<300 \mu \mathrm{g} / \mathrm{g}$, which is consistent with low total sulfur contents determined in previously analyzed samples from Site U1529 and also in line with published data for Brothers volcano (Haase et al., 2006). It also suggests minimal influence of magmatic volatile input in selected samples. However, relatively high concentrations of $\mathrm{H}_{2}$ and acid-volatile sulfide (AVS) were detected in pore spaces in some intervals, which is possibly indicative of magmatic gases discharging through the volcanic pile. $\mathrm{TN}$ is below detection limit $(<20 \mu \mathrm{g} / \mathrm{g})$ for all Site U1531 samples (Table T6). Overall, all Site U1531 samples contain low total volatile content.

\section{Headspace analysis of $\mathrm{H}_{2}, \mathrm{CO}, \mathrm{CH}_{4}, \mathrm{C}_{2} \mathrm{H}_{6}$, $\Sigma \mathrm{CO}_{2}$, and AVS}

Pore space dissolved gas concentration, including $\mathrm{H}_{2}, \mathrm{CO}, \mathrm{CH}_{4}$, $\mathrm{C}_{2} \mathrm{H}_{6}$, and $\Sigma \mathrm{CO}_{2}$, were determined by headspace analysis of samples from Holes U1531A-U1531C (Table T7). For Sites U1528 and U1530 (see Geochemistry in the Expedition 376 methods chapter [de Ronde et al., 2019a]), we also measured the concentrations of pore fluid AVS.

Dissolved $\mathrm{C}_{2} \mathrm{H}_{6}$ concentration was below the detection limit $(<0.03 \mu \mathrm{mol} / \mathrm{L})$ for all Site U1531 samples, as they were at other sites. Relatively high $\mathrm{H}_{2}$ concentrations (46.1-283 $\mu \mathrm{mol} / \mathrm{L}$ ) were detected in the pore space of samples from $0.89 \mathrm{mbsf}$ (Section 376-U1531A1R-1), 0.06 mbsf (Section 376-U1531B-1R-1), and 1.37 mbsf (Section 376-U1531C-1R-1), whereas detectable AVS concentrations (200$755 \mu \mathrm{mol} / \mathrm{L}$ ) were obtained from samples at $0.89 \mathrm{mbsf}$ (Section 376U1531A-1R-1), 20.35 mbsf (Section 376-U1531B-3R-3), and 15.33 mbsf (Section 376-U1531C-2R-1) (Table T7). These elevated concentrations of $\mathrm{H}_{2}$ and AVS may be related to hydrothermal fluid flow.
Figure F8. Total alkali $\left(\mathrm{Na}_{2} \mathrm{O}+\mathrm{K}_{2} \mathrm{O}\right)$ vs. silica $\left(\mathrm{SiO}_{2}\right)$, Igneous Unit 1. Data are reported for fresh dacites from Hole U1527A and unaltered to slightly altered dacitic clasts and tephra from Sites U1531 and U1529. Major element oxide concentrations were recalculated to $100 \%$ on a volatile-free basis. Additional data for comparison include (1) dacitic to rhyolitic glasses and whole rock from Brothers volcano reported in previous studies (Haase et al., 2006; Wright and Gamble, 1999; Timm et al., 2012) and (2) subaerial lava recovered along the Kermadec arc $\left(25^{\circ}-37^{\circ} \mathrm{S}\right)$ (data compiled from the GEOROC geochemical database at http://georoc.mpch-mainz.gwdg.de /georoc; downloaded on 5 June 2018).

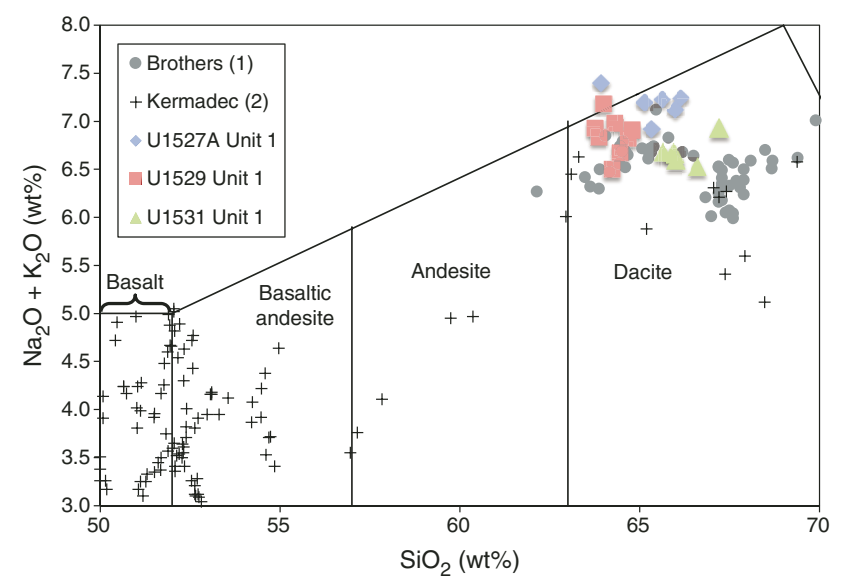

Table T6. Total carbon (TC), total nitrogen (TN), and total sulfur (TS) measured by the elemental analyzer, Holes U1531A-U1531C. Download table in CSV format.

Table T7. Pore water gas concentrations, Holes U1531A-U1531C. Download table in CSV format.

However, $\Sigma \mathrm{CO}_{2}$ concentrations range from 28.6 to $2850 \mu \mathrm{mol} / \mathrm{L}$, similar to or much lower than the dissolved inorganic carbon (DIC) concentration in seawater $(\sim 2.4 \mathrm{mmol} / \mathrm{L})$ (Table T7). If magmatic gas input had contributed to the pore fluid gas compositions of the core samples, $\Sigma \mathrm{CO}_{2}$ concentrations would have been expected to exceed seawater DIC values and would have been associated with a concomitant increase in $\mathrm{H}_{2}$ and AVS concentrations, as observed at Site U1528 (see Geochemistry). Thus, the relatively high concentration of $\mathrm{H}_{2}$ observed in headspace analyses for Site U1531 may instead be derived from mechanochemical $\mathrm{H}_{2}$ production during drilling and/or crushing of the rock core samples (see Geochemistry). AVS may be contributed from AVS-containing minerals such as Fe sulfide phases in the fresh to slightly altered dacitic material.

\section{Paleomagnetism}

At Site U1531, only three core sections recovered from Hole U1531C to a maximum depth of $\sim 15$ mbsf had oriented pieces larger than $\sim 10 \mathrm{~cm}$ that could be measured in the cryogenic SRM. Any overprint magnetization that resulted from coring was removed using in-line AF demagnetization up to $70 \mathrm{mT}$. We first measured each archive half using the cryogenic magnetometer in continuous sampling mode, and then we analyzed subsections of the archive half at the intervals of the largest oriented pieces using PuffinPlot (version 1.0.3; Lurcock and Wilson, 2012). It is important to recognize that, as at the other Brothers volcano sites, this is a nonstandard measurement and care should be taken when using the 
magnetization directions and intensities from the shipboard Laboratory Information Management System (LIMS) database because discontinuous recovery compromises an accurate measurement of the magnetization parameters. Five discrete samples from Site U1531 working halves were selected for detailed measurements of AMS, AF and TD, and IRM experiments.

\section{Igneous Unit 1}

The NRM of three samples (Table T8) was measured before and after AF demagnetization up to $200 \mathrm{mT}$ (Figure F9). In general, relatively large NRM intensities up to $\sim 2 \mathrm{~A} / \mathrm{m}$ were also measured before AF demagnetization for these samples, which is in agreement with the results from archive halves measured with the SRM. The soft magnetic drilling overprint (Richter et al., 2007) was removed after AF demagnetization of $10 \mathrm{mT}$, leaving primary components that could be analyzed with principal component analysis (PCA; Kirschvink, 1980) in vector component diagrams (Zijderveld, 1967). The AF demagnetized samples show relatively large coercivities (>100 mT; confirmed by further IRM experiments) and inclination values of approximately $-60^{\circ}$. These values are very similar to the corresponding values measured for Igneous Unit 1 at Site U1527 (see Figure F38 in the Site U1527 chapter [de Ronde et al., 2019b]).

Table T8. Discrete samples, measurements, and experiments, Hole U1531C. All samples were measured for anisotropy magnetic susceptibility and isothermal remanent magnetization. $\mathrm{TD}=$ thermal demagnetization, $\mathrm{AF}=$ alternating field demagnetization. Download table in CSV format.

\begin{tabular}{lccc}
\hline $\begin{array}{c}\text { Core, section, } \\
\text { interval }(\mathrm{cm})\end{array}$ & Sample ID & $\begin{array}{c}\text { Igneous } \\
\text { unit }\end{array}$ & $\begin{array}{c}\text { Treatment } \\
\left({ }^{\circ} \mathrm{C}, \mathrm{mT}\right)\end{array}$ \\
\hline $\begin{array}{c}376-\mathrm{U} 1531 \mathrm{C}- \\
1 \mathrm{R}-1,90-92\end{array}$ & CUBE9672251 & 1 & TD 610 \\
$1 \mathrm{R}-2,17-19$ & CUBE9672261 & 1 & AF 200 \\
$2 \mathrm{R}-1,6-8$ & CUBE9672271 & 1 & TD 610 \\
$1 \mathrm{R}-1,133-135$ & CUBE9677341 & 1 & AF 200 \\
$1 \mathrm{R}-1,9-11$ & CUBE9677201 & 1 & AF 200 \\
\hline
\end{tabular}

Figure F9. AF demagnetization experiment showing univectorial decay in Sample 376-U1531C-1R-1, 133-135 cm, with a large NRM before demagnetization $(1.92 \mathrm{~A} / \mathrm{m})$. This sample shows high coercivity and stable primary magnetization for $\mathrm{AF}>10 \mathrm{mT}$.

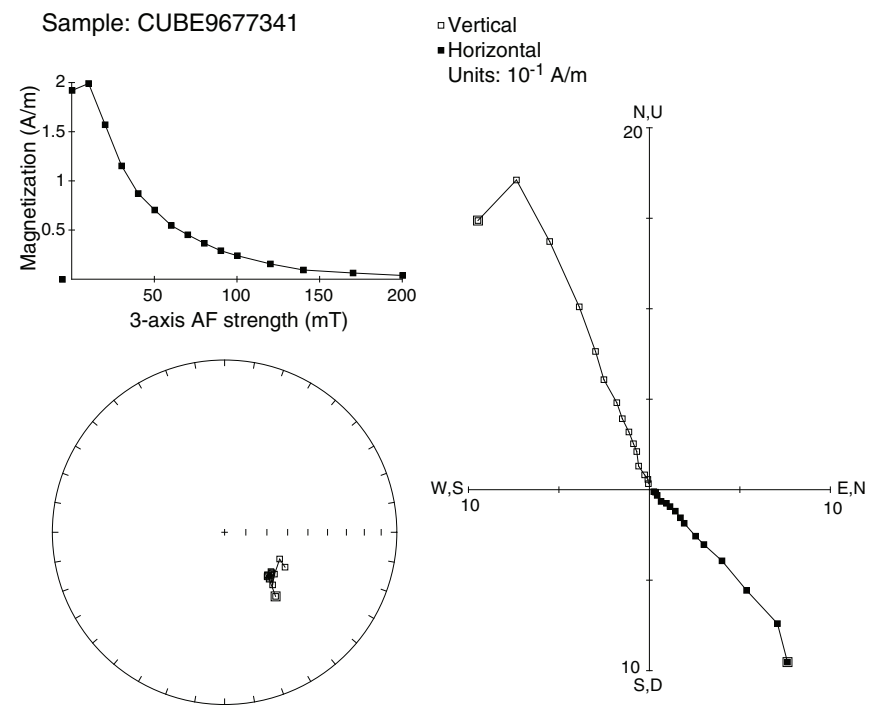

TD experiments were conducted on two other samples. After measuring NRM at room temperature, the samples were shared with the Physical Properties group for moisture and density (MAD) measurements, which required heating the samples to $105^{\circ} \mathrm{C}$. The initial large NRM intensities measured before TD $(4.37-6.25 \mathrm{~A} / \mathrm{m})$ were also in agreement with the values from the archive halves measured with the SRM. After the MAD measurements, these samples were thermally demagnetized up to a maximum temperature of $610^{\circ} \mathrm{C}$ starting from an initial step of $110^{\circ} \mathrm{C}$ to erase any magnetic overprint as a result of MAD measurements. The samples show a linear decrease of magnetization intensity to $\sim 40 \%$ of the original intensity at temperatures around $400^{\circ} \mathrm{C}$, complete demagnetization at $580^{\circ} \mathrm{C}$ (Figure F10), and an inclination of approximately $-60^{\circ}$. These TD curves are very similar to the corresponding thermal curves from discrete samples from Igneous Unit 1 at Site U1527 (see Figure F39 in the Site U1527 chapter [de Ronde et al., 2019b]). Mean susceptibilities measured by the AGICO Kappabridge KLY-4 for the six fresh to slightly altered dacite samples are high $\left(\sim 2000 \times 10^{-5} \mathrm{SI}\right)$ and are in agreement with continuous susceptibility measurements (see Physical properties).

\section{Discussion}

Magnetic directions calculated using PCA on the five discrete samples consistently show univectorial decay toward the origin and an inclination of about $-60^{\circ}$. This set of directions is assumed to represent remanent magnetization recorded at the time these rocks cooled. Average inclinations for both lithologies are very similar to the geomagnetic axial dipole inclination of $-55^{\circ}$. This indicates a very young age for the primary magnetization component and almost certainly from the current normal Chron C1n (Cande and Kent, 1995). The shape of the TD curve suggests that these samples contain pure magnetite (Curie temperature $=\sim 575^{\circ} \mathrm{C}$; Tauxe, 2010) and titanomagnetite with variable $\mathrm{Ti}$ content because increasing $\mathrm{Ti}$ content produces a decrease of the Curie temperature (O'Reilly, 1984). The relatively high coercivities measured on discrete samples and archive halves suggest the prevalence of single-domain mag-

Figure F10. TD experiment using Sample 376-U1531A-1R-1, 90-92 cm, with a large NRM before demagnetization $(6.25 \mathrm{~A} / \mathrm{m})$. The drilling overprint in this experiment was removed at temperatures $>200^{\circ} \mathrm{C}$, leaving a stable primary component.
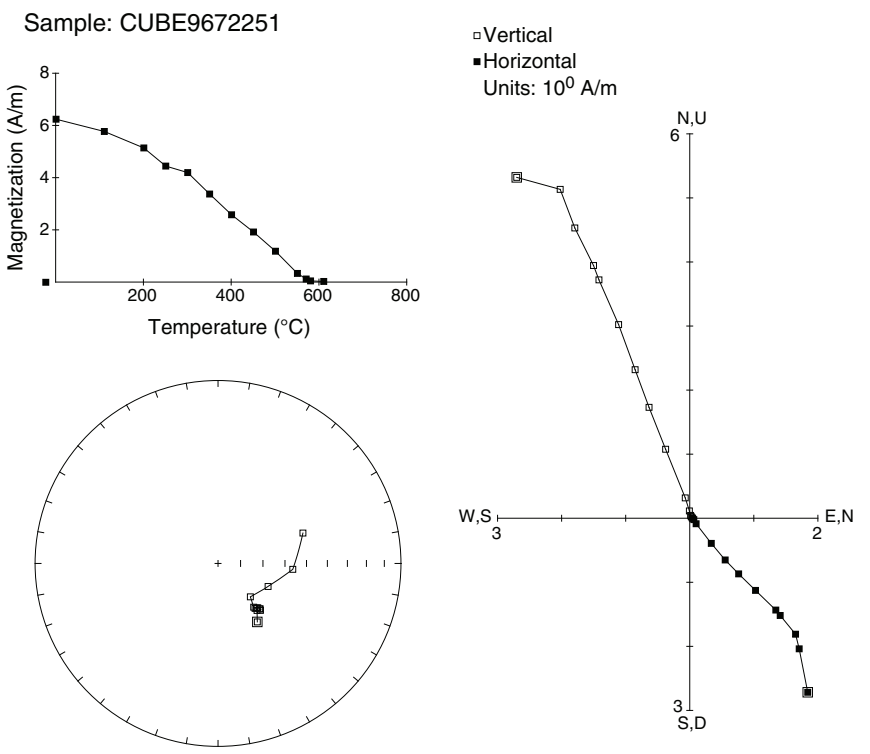
netic grains (Tauxe, 2010). No significant transformation of magnetic minerals during heating is evident from the TD curves. The large mean susceptibilities for the six samples from Igneous Unit 1 imply a significant content of magnetite $(0.2-0.5 \mathrm{vol} \%)$ using the empirical relation of Grant and West (1965).

\section{Physical properties}

Physical property data for Site U1531 were obtained for cores from the flank (Holes U1531A, U1531B, and U1531E) and summit (Hole U1531C) of the Lower Cone (Figure F11). Cores were left to equilibrate to room temperature $\left(\sim 20^{\circ} \mathrm{C}\right)$ prior to further analyses.
Cores are commonly in multiple pieces of various length, so continuous measurements on whole-round cores (i.e., gamma ray attenuation bulk density, magnetic susceptibility [MS], and natural gamma radiation [NGR]) yielded poor data quality (see Physical properties in the Expedition 376 methods chapter [de Ronde et al., 2019a]). Measurements of $P$-wave velocity, density, porosity, MS, and thermal conductivity made on section halves and discrete samples, therefore, provide the basis for the petrophysical characterization of Site U1531. In total, 12 discrete samples were analyzed, including cut cubes, tephra, and loose bomb/block-sized clasts. Cube samples were used for paleomagnetic, MAD, and $P$-wave measurements. Thermal conductivity was measured on three pieces of working halves.

Figure F11. Physical properties, Hole U1531C (Lower Cone summit; top) and Holes U1531A, U1531B, and U1531E (Lower Cone flank; bottom). P-wave velocity values are the mean for each set of measurements. Lithology columns are aligned such that recovered core intervals correspond to the depths shown in the plots to reflect the Lower Cone summit vs. flank location and associated distinct water depths at the seafloor.
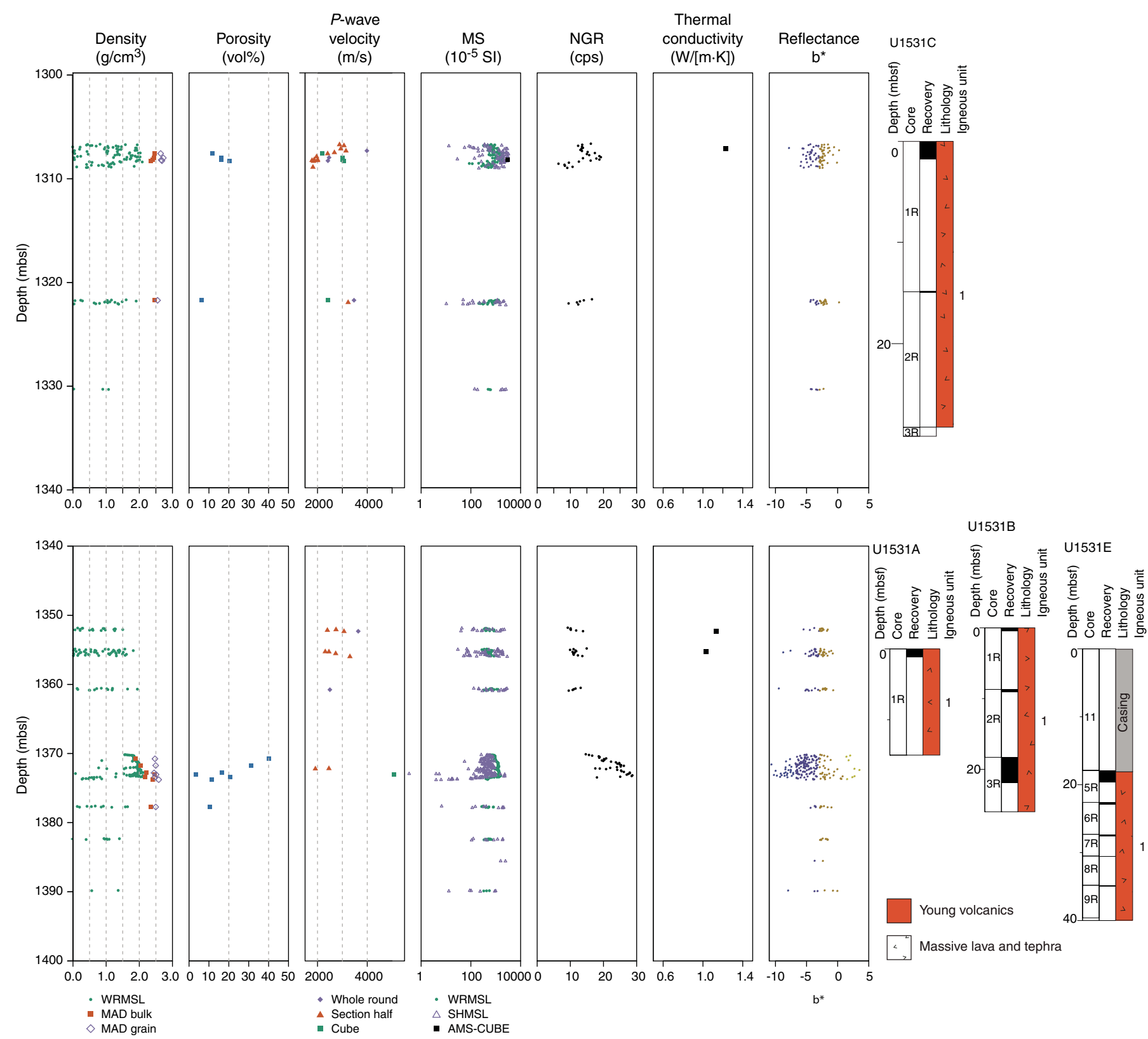


\section{Density and porosity}

Individual MAD porosity and bulk, dry, and grain density for all holes at Site U1531 are shown in Table T9. Data for Lower Cone flank samples (Holes U1531B and U1531E) are shown in the lower half of Figure F11, and data for Lower Cone summit samples (Hole U1531C) are shown in the upper half. Bulk density for Lower Cone flank samples ranges from 1.89 to $2.46 \mathrm{~g} / \mathrm{cm}^{3}$ with a mean of $2.22 \mathrm{~g} / \mathrm{cm}^{3}$, and bulk density for Lower Cone summit samples ranges from 2.35 to $2.46 \mathrm{~g} / \mathrm{cm}^{3}$ with a mean of $2.42 \mathrm{~g} / \mathrm{cm}^{3}$. Grain density for Lower Cone flank samples ranges from 2.45 to

Table T9. Moisture and density data, Holes U1531B, U1531C, and U1531E. Download table in CSV format.
$2.59 \mathrm{~g} / \mathrm{cm}^{3}$ with a mean of $2.50 \mathrm{~g} / \mathrm{cm}^{3}$, whereas grain density for Lower Cone summit samples ranges from 2.55 to $2.73 \mathrm{~g} / \mathrm{cm}^{3}$ with a mean of $2.65 \mathrm{~g} / \mathrm{cm}^{3}$. Porosity for Lower Cone flank samples ranges from 3 to 40 vol\% with a mean of 19 vol\%; porosity for Lower Cone summit samples ranges from 6 to 20 vol\% with a mean of 14 vol\%.

Porosity is inversely correlated to bulk density across all holes (Figure F12). Variations in density and porosity with depth are difficult to assess because of limited core recovery. However, the relatively continuous recovery in Core 376-U1531B-3R, which contains unconsolidated volcaniclastic material from the Lower Cone flank, shows an increase in bulk density with depth (from 1.90 to 2.41 $\mathrm{g} / \mathrm{cm}^{3}$ between 18.9 and $21.91 \mathrm{mbsf}$ ) and a corresponding decrease in porosity from 40 to $11 \mathrm{vol} \%$.

Figure F12. MAD P-wave velocity data for discrete samples, Holes U1531B, U1531C, and U1531E. Line shows best fit from linear regression.
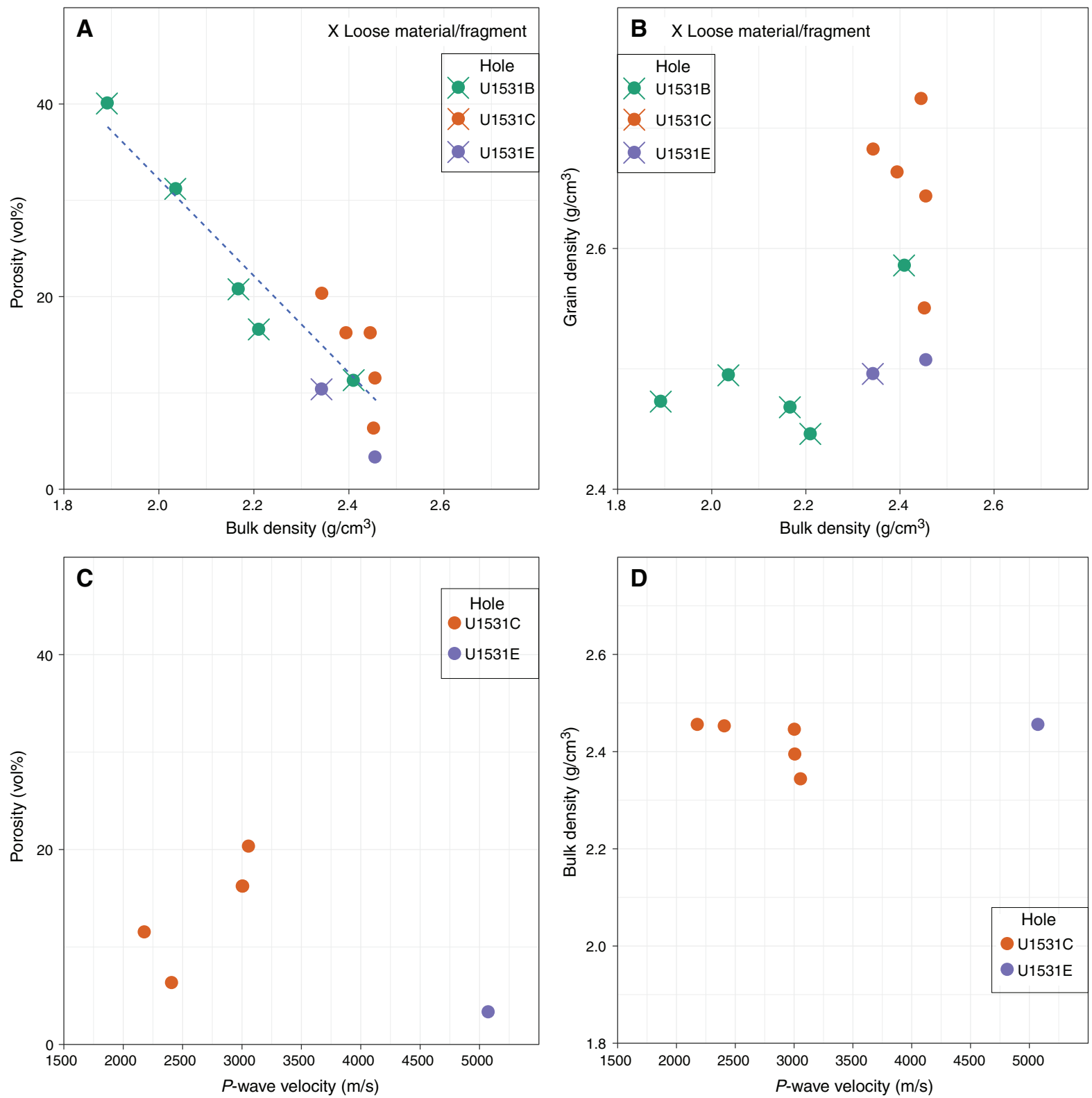


\section{$P$-wave velocity}

$P$-wave velocity measurements included 11 measurements on whole-round core pieces in the $x$ - and $y$-directions, 24 measurements on section halves in the $x$-direction, and measurements on seven discrete cubes in the $x$-, $y$-, and $z$-directions. Measured velocities are consistent between the three measurement types.

$P$-wave velocity ranges from $\sim 1780$ to $\sim 5080 \mathrm{~m} / \mathrm{s}$ with a median of $\sim 2700 \mathrm{~m} / \mathrm{s}$. Measured $P$-wave velocity and calculated anisotropy data are shown in Table T10. The highest values $(>5000 \mathrm{~m} / \mathrm{s})$ correspond to a discrete cube cut from an unoriented piece in Section 376-U1531E-5R-1. P-wave anisotropy values for the remaining discrete cubes from Hole U1531E range from $2 \%$ to $10 \%$ between the $z$ direction (vertical) and the $x-y$ plane (horizontal). $P$-wave anisotropies between the $x$ - and $y$-axes for discrete cubes (Hole U1531C) and pieces of whole-round core (Holes U1531B and U1531C) vary between $0 \%$ and $21 \%$. No discernible trend is evident in anisotropy or preferred fast direction with depth.

$P$-wave measurements were also performed on Core 376U1531B-3R using the Whole-Round Multisensor Logger (WRMSL) $P$-wave velocity logger (PWL). This was possible because the volcaniclastic material fully filled the core liner. These values reach a maximum of $1771 \mathrm{~m} / \mathrm{s}$ with an average of $\sim 1660 \mathrm{~m} / \mathrm{s}$ (Figure F11). No visible trend with depth was observed in the PWL data for this core.

\section{Magnetic susceptibility}

MS data include WRMSL magnetic susceptibility loop (MSL) measurements on whole-round cores, Section Half Multisensor Logger (SHMSL) point magnetic susceptibility (MSP) measurements on working halves, and bulk MS measurements of discrete cubes (see Paleomagnetism) (Figure F11). MSP for Lower Cone flank samples (Holes U1531A, U1531B, and U1531E) has a mean of $\sim 600 \times 10^{-5} \mathrm{SI}$ and a maximum of $2889 \times 10^{-5} \mathrm{SI}$ at $1.12 \mathrm{mbsf}$ (Section 376-U1531A-1R-1). MSP for Lower Cone summit samples (Hole U1531C) has a mean of $1300 \times 10^{-5} \mathrm{SI}$ and a maximum of $3240 \times 10^{-5}$ at $0.96 \mathrm{mbsf}$ (Section 376-U1530C-1R-1). SHMSL MSP, WRMSL MS, and bulk MS data are all in reasonable agreement.

\section{Natural gamma radiation}

NGR for Site U1531 is between 6 and 28 counts/s, with the maximum recorded in the unconsolidated volcanic material of Section 376-U1531B-3R-3 at 21.35 mbsf (Figure F11).

\section{Thermal conductivity}

Thermal conductivity was measured on only three samples from Site U1531 because of the small size or unconsolidated nature of the recovered material. Measurements range from 1.03 to 1.23 $\mathrm{W} /(\mathrm{m} \cdot \mathrm{K})$ and have a mean value of $1.13 \mathrm{~W} /(\mathrm{m} \cdot \mathrm{K})$ (Figure F11; Table T11).

Table T10. P-wave velocity data, Holes U1531A-U1531C and U1531E. Download table in CSV format.

Table T11. Thermal conductivity data, Holes U1531A-U1531C. Download table in CSV format.

\section{Reflectance colorimetry}

Reflectance colorimetry values show no significant variations, which is consistent with the homogeneous black to dark gray color of the recovered material from all holes at Site U1531 (Figure F11).

\section{Integration of observations}

Physical property measurements made on limited fragmented core recovered from Holes U1531A-U1531C and U1531E are consistent with the range of expected values for fresh dacite lava and tephra and similar to values found for similar unaltered volcaniclastic material in Igneous Unit 1 at Sites U1527-U1529.

The wide range in measured $P$-wave velocity at Site U1531 reflects the variety of recovered material. $P$-wave measurements of saturated unconsolidated volcaniclastics in Core 376-U1531B-3R have some of the lowest values at this site because of their high water content and are comparable to those of Core 376-U1528A-1R and to the reported $P$-wave velocity of water-rich sediments recovered from the Nankai Trough, Japan (Schumann et al., 2014). Bulk density and porosity also have wide ranges of values, including the low bulk density and high porosity of saturated unconsolidated volcaniclastics and the variable bulk density and porosity of individual lava clasts. No clear difference in the physical properties of material recovered from the summit of the Lower Cone and material recovered from the flank is evident, although further interpretation is limited by the low recovery, the fragmented nature of the core, and the limited number of oriented pieces.

\section{Downhole measurements}

The ETBS memory tool was run in to Hole U1531E after $\sim 24 \mathrm{~h}$ without circulation. The tool indicated a maximum temperature of $5.2^{\circ} \mathrm{C}$ at $20 \mathrm{mbsf}$, which is similar to bottom seawater temperature.

\section{Microbiology}

At Site U1531, one whole-round sample (376-U1531C-1R-2, 8.5-15 cm) was collected from Hole U1531C for microbiological analysis. This sample represents a moderately vesicular dacite lava from Igneous Unit 1 (Figure F13) (see Igneous petrology and volcanology). We took a sample aliquot from the sampled wholeround core material for shore-based DNA and RNA analyses and prokaryotic and viral counting and activity measurements.

Figure F13. Whole-round sample collected for microbiological analyses, Hole U1531C.

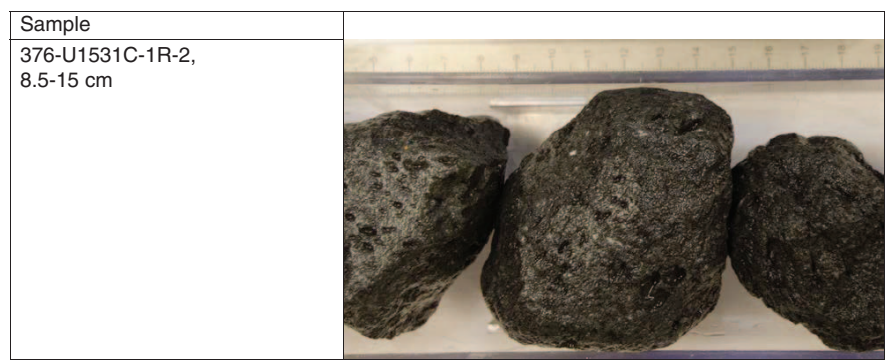




\section{References}

Cande, S.C., and Kent, D.V., 1995. Revised calibration of the geomagnetic polarity timescale for the Late Cretaceous and Cenozoic. Journal of Geophysical Research: Solid Earth, 100(B4):6093-6095. https://doi.org/10.1029/94JB03098

de Ronde, C.E.J., Humphris, S.E., and Höfig, T.W., 2017. Expedition 376 Scientific Prospectus: Brothers Arc Flux. International Ocean Discovery Program. https://doi.org/10.14379/iodp.sp.376.2017

de Ronde, C.E.J., Humphris, S.E., Höfig, T.W., Brandl, P.A., Cai, L., Cai, Y., Caratori Tontini, F., Deans, J.R., Farough, A., Jamieson, J.W., Kolandaivelu, K.P., Kutovaya, A., Labonté, J.M., Martin, A.J., Massiot, C., McDermott, J.M., McIntosh, I.M., Nozaki, T., Pellizari, V.H., Reyes, A.G., Roberts, S., Rouxel, O., Schlicht, L.E.M., Seo, J.H., Straub, S.M., Strehlow, K., Takai, K., Tanner, D., Tepley, F.J., III, and Zhang, C., 2019a. Expedition 376 methods. In de Ronde, C.E.J., Humphris, S.E., Höfig, T.W., and the Expedition 376 Scientists, Brothers Arc Flux. Proceedings of the International Ocean Discovery Program, 376: College Station, TX (International Ocean Discovery Program). https://doi.org/10.14379/iodp.proc.376.102.2019

de Ronde, C.E.J., Humphris, S.E., Höfig, T.W., Brandl, P.A., Cai, L., Cai, Y., Caratori Tontini, F., Deans, J.R., Farough, A., Jamieson, J.W., Kolandaivelu, K.P., Kutovaya, A., Labonté, J.M., Martin, A.J., Massiot, C., McDermott, J.M., McIntosh, I.M., Nozaki, T., Pellizari, V.H., Reyes, A.G., Roberts, S., Rouxel, O., Schlicht, L.E.M., Seo, J.H., Straub, S.M., Strehlow, K., Takai, K., Tanner, D., Tepley, F.J., III, and Zhang, C., 2019b. Site U1527. In de Ronde, C.E.J., Humphris, S.E., Höfig, T.W., and the Expedition 376 Scientists, Brothers Arc Flux. Proceedings of the International Ocean Discovery Program, 376: College Station, TX (International Ocean Discovery Program). https://doi.org/10.14379/iodp.proc.376.103.2019

de Ronde, C.E.J., Humphris, S.E., Höfig, T.W., Brandl, P.A., Cai, L., Cai, Y., Caratori Tontini, F., Deans, J.R., Farough, A., Jamieson, J.W., Kolandaivelu, K.P., Kutovaya, A., Labonté, J.M., Martin, A.J., Massiot, C., McDermott, J.M., McIntosh, I.M., Nozaki, T., Pellizari, V.H., Reyes, A.G., Roberts, S., Rouxel, O., Schlicht, L.E.M., Seo, J.H., Straub, S.M., Strehlow, K., Takai, K., Tanner, D., Tepley, F.J., III, and Zhang, C., 2019c. Site U1528. In de Ronde, C.E.J., Humphris, S.E., Höfig, T.W., and the Expedition 376 Scientists, Brothers Arc Flux. Proceedings of the International Ocean Discovery Program, 376: College Station, TX (International Ocean Discovery Program). https://doi.org/10.14379/iodp.proc.376.104.2019

de Ronde, C.E.J., Humphris, S.E., Höfig, T.W., Brandl, P.A., Cai, L., Cai, Y., Caratori Tontini, F., Deans, J.R., Farough, A., Jamieson, J.W., Kolandaivelu, K.P., Kutovaya, A., Labonté, J.M., Martin, A.J., Massiot, C., McDermott, J.M., McIntosh, I.M., Nozaki, T., Pellizari, V.H., Reyes, A.G., Roberts, S., Rouxel, O., Schlicht, L.E.M., Seo, J.H., Straub, S.M., Strehlow, K., Takai, K., Tanner, D., Tepley, F.J., III, and Zhang, C., 2019d. Site U1529. In de Ronde, C.E.J., Humphris, S.E., Höfig, T.W., and the Expedition 376 Scientists, Brothers Arc Flux. Proceedings of the International Ocean Discovery Program, 376: College Station, TX (International Ocean Discovery Program). https://doi.org/10.14379/iodp.proc.376.105.2019

de Ronde, C.E.J., Humphris, S.E., Höfig, T.W., Brandl, P.A., Cai, L., Cai, Y., Caratori Tontini, F., Deans, J.R., Farough, A., Jamieson, J.W., Kolandaivelu, K.P., Kutovaya, A., Labonté, J.M., Martin, A.J., Massiot, C., McDermott, J.M., McIntosh, I.M., Nozaki, T., Pellizari, V.H., Reyes, A.G., Roberts, S., Rouxel, O., Schlicht, L.E.M., Seo, J.H., Straub, S.M., Strehlow, K., Takai, K., Tanner, D., Tepley, F.J., III, and Zhang, C., 2019e. Site U1530. In de Ronde, C.E.J., Humphris, S.E., Höfig, T.W., and the Expedition 376 Scientists, Brothers Arc Flux. Proceedings of the International Ocean Discovery Program, 376: College Station, TX (International Ocean Discovery Program). https://doi.org/10.14379/iodp.proc.376.106.2019

de Ronde, C.E.J., Humphris, S.E., Höfig, T.W., and the Expedition 376 Scientists, 2019b. Supplementary material,

https://doi.org/10.14379/iodp.proc.376supp.2019. Supplement to de Ronde, C.E.J., Humphris, S.E., Höfig, T.W., and the Expedition 376 Scientists, 2019. Brothers Arc Flux. Proceedings of the International Ocean
Discovery Program, 376: College Station, TX (International Ocean Discovery Program). https://doi.org/10.14379/iodp.proc.376.2019

Embley, R.W., de Ronde, C.E.J., Merle, S.G., Davy, B., and Catatoni Tontini, F., 2012. Detailed morphology and structure of an active submarine arc caldera: Brothers Volcano, Kermadec arc. Economic Geology,107(8):15571570. https://doi.org/10.2113/econgeo.107.8.1557

Fisher, R.V., and Schmincke, H.-U., 1984. Pyroclastic Rocks: Berlin (SpringerVerlag). https://doi.org/10.1007/978-3-642-74864-6

Graham, I.J., Reyes, A.G., Wright, I.C., Peckett, K.M., Smith, I.E.M., and Arculus, R.J., 2008. Structure and petrology of newly discovered volcanic centers in the northern Kermadec-southern Tofua arc, South Pacific Ocean. Journal of Geophysical Research: Solid Earth, 113(B8):B08S02. https://doi.org/10.1029/2007JB005453

Grant, F.S., and West, G.F., 1965. Interpretation Theory in Applied Geophysics: New York (McGraw-Hill).

Grove, T.L., Baker, M.B., Price, R.C., Parman, S.W., Elkins-Tanton, L.T., Chatterjee, N., and Müntener, O., 2005. Magnesian andesite and dacite lavas from Mt. Shasta, northern California: products of fractional crystallization of $\mathrm{H}_{2} \mathrm{O}$-rich mantle melts. Contributions to Mineralogy and Petrology, 148(5):542-565. https://doi.org/10.1007/s00410-004-0619-6

Haase, K.M., Stroncik, N., Garbe-Schönberg, D., and Stoffers, P., 2006. Formation of island arc dacite magmas by extreme crystal fractionation: an example from Brothers Seamount, Kermadec island arc (SW Pacific). Journal of Volcanology and Geothermal Research, 152(3-4):316-330. https://doi.org/10.1016/j.jvolgeores.2005.10.010

Keith, M., Haase, K.M., Klemd, R., Smith, D.J., Schwarz-Schampera, U., and Bach, W., 2018. Constraints on the source of $\mathrm{Cu}$ in a submarine magmatic-hydrothermal system, Brothers volcano, Kermadec island arc. Contributions to Mineralogy and Petrology, 173(5):40. https://doi.org/10.1007/s00410-018-1470-5

Kirschvink, J.L., 1980. The least-squares line and plane and the analysis of palaeomagnetic data. Geophysical Journal of the Royal Astronomical Society, 62(3):699-718. https://doi.org/10.1111/j.1365-246X.1980.tb02601.x

Lurcock, P.C., and Wilson, G.S., 2012. PuffinPlot: a versatile, user-friendly program for paleomagnetic analysis. Geochemistry, Geophysics, Geosystems, 13(6):Q06Z45. https://doi.org/10.1029/2012GC004098

Millet, M.-A., Tutt, C.M., Handler, M.R., and Baker, J.A., 2014. Processes and time scales of dacite magma assembly and eruption at Tauhara volcano, Taupo Volcanic Zone, New Zealand. Geochemistry, Geophysics, Geosystems, 15(1):2013-237. https://doi.org/10.1002/2013GC005016

O'Reilly, W., 1984. Rock and Mineral Magnetism: New York (Chapman and Hall). https://doi.org/10.1007/978-1-4684-8468-7

Richter, C., Acton, G., Endris, C., and Radsted, M., 2007. Technical Note 34: Handbook for Shipboard Paleomagnetists. Ocean Drilling Program. https://doi.org/10.2973/odp.tn.34.2007

Schumann, K., Stipp, M., Behrmann, J.H., Klaeschen, D., and Schulte-Kortnack, D., 2014. $P$ and $S$ wave velocity measurements of water-rich sediments from the Nankai Trough, Japan. Journal of Geophysical Research: Solid Earth, 119(2):787-805. https://doi.org/10.1002/2013JB010290

Tauxe, L., 2010. Essentials of Paleomagnetism: Berkeley, California (University of California Press).

Timm, C., de Ronde, C.E.J., Leybourne, M.I., Layton-Matthews, D., and Graham, I.J., 2012. Sources of chalcophile and siderophile elements in Kermadec arc lavas. Economic Geology, 107(8):1527-1538. https://doi.org/10.2113/econgeo.107.8.1527

Wright, I.C., and Gamble, J.A., 1999. Southern Kermadec submarine caldera arc volcanoes (SW Pacific): caldera formation by effusive and pyroclastic eruption. Marine Geology, 161(2-4):207-227. https://doi.org/10.1016/S0025-3227(99)00040-7

Zijderveld, J.D.A., 1967. AC demagnetization of rocks: analysis of results. In Collinson, D.W., Creer, K.M., and Runcorn, S.K. (Eds.), Developments in Solid Earth Geophysics (Volume 3): Methods in Palaeomagnetism: Amsterdam (Elsevier), 254-286. https://doi.org/10.1016/B978-1-4832-2894-5.50049-5 